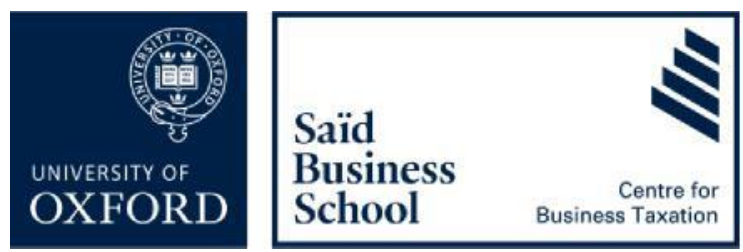

\title{
What are Minimum Taxes, and Why Might One Favor or Disfavor Them?
}

WP 20/04

June 2020

Daniel Shaviro

N.Y.U Law School 


\section{What ARE Minimum TAXES, AND Why Might One FAVOR OR DISFAVOR THEM?}

Daniel Shaviro*

June 9, 2020

Revised Draft

All Rights Reserved

\section{Table of Contents}

Introduction 2

I. Minimum Taxes Historically and Conceptually ……………………......................... 4

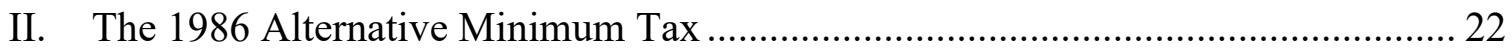

A. From "Just One Cent" to a Preference Rationing Rule............................................... 22

B. Post-1986 Decline and (Partial) Fall of the AMT ..................................................... 29

III. A Minimum or Other Tax on Corporate Financial Statement Income? ................... 37

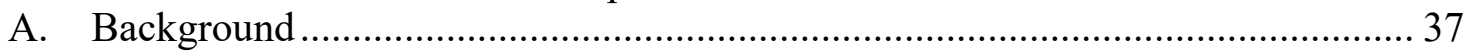

B. Significance of the Main Rationales for Taxing Book Income ............................ 40

1. Optical Effects of Not Taxing Companies with Large Reported Profits........... 40

2. Aim of Raising Overall Corporate Tax Burdens............................................. 40

3. Suspected Underlying Corporate Tax Avoidance ............................................ 41

C. Empirical Issues Raised in the Debate Over Taxing (or Not) Book Income........ 42

1. Effects on Managerial Agency Costs and the Quality of Information Supplied to Investors 42

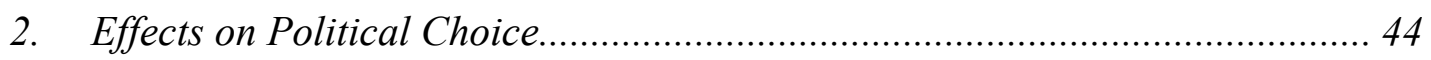

D. Further Design Issues Raised by Taxing Book Income......................................... 45

1. International Issues................................................................................. 45

2. Annual Accounting and the Effects of Timing Differences Between the Systems 47

E. Summing Up, and Broader Takeaways ............................................................. 49

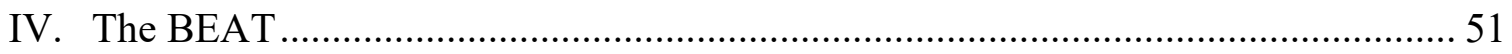

A. Technical Versus Purposive Minimum Taxes ........................................................ 51

B. Relevance of the BEAT's Being Technically a Minimum Tax........................... 53

1. Incentive to Manage the Relationship Between Regular Tax and BEAT Liability 53

2. Division of firms into regular tax-minimizing and BEAT-minimizing clienteles 56

C. Relevance of the BEAT's Not Being Purposively a Minimum Tax...................... 57

D. Summing Up ……................................................................................. 59

\footnotetext{
* Wayne Perry Professor of Taxation, N.Y.U. Law School. I am grateful to Ryan Fackler for excellent research assistance, and to Kimberly Clausing, Leandra Lederman, Ruth Mason, Stephen Shay, and James Wetzler for helpful comments on an earlier draft.
} 
V. Loss Nonrefundability and Foreign Tax Credit Limitations................................. 61

VI. Foreign Tax Credit Systems and Global Minimum Taxes ................................... 65

A. Global Minimum Taxes and the Surrounding Neighborhood ................................ 66

1. The Global Minimum Tax Character of the Pre-2017 U.S. International Tax Regime 66

2. $\quad$ Pre-2017 U.S. Global Minimum Tax Proposals ............................................ 68

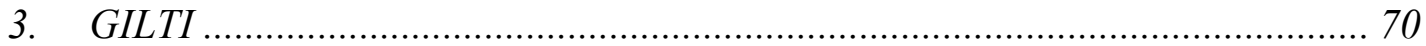

4. Pillar Two of the OECD's GloBE Proposal ..................................................... 72

B. Choosing MRRs for Resident MNCs’ Foreign Tax Liabilities .............................. 73

C. MRRs and the Use of a Global Minimum Tax Structure ....................................... 78

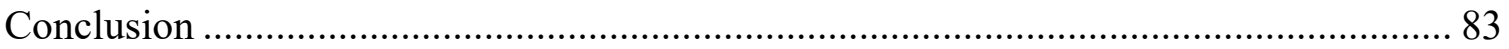

\section{INTRODUCTION}

Responsible taxation, in the aftermath of any decently full recovery from the COVID-19 pandemic, is bound to require the "plucking" of enough new "feathers" to guarantee plenty of taxpayer "hissing." ${ }^{1}$ It also, in the view of many, should involve imposing significant new tax liabilities on wealthy individuals and highly profitable corporations, especially those otherwise paying little tax.

Each of these two considerations might have sufficed to assure the reemergence into public view, in post-pandemic policy debate, of provisions called minimum taxes, if not for one thing. Minimum taxes could not re-emerge after the start of the pandemic, because they had already preceded it into public view. Its fiscal depredations will, however, increase the urgency of comparing them to other techniques for increased "plucking."

Minimum taxes' structural merits and defects offer a natural topic of inquiry. They have a significant historical track record that offers instructive guidance. In addition,

\footnotetext{
${ }^{1}$ I refer to the famous statement, attributed to Louis XIV's finance minister, Jean-Baptiste Colbert, that "the art of taxation consists in so plucking the goose as to obtain the largest possible amount of feathers with the smallest possible amount of hissing."
} 
despite their internal variations and lack of complete distinctness from other fiscal instruments, they have enough in common to ground a detailed analysis. However, the literature to date has tended to focus on particular types of minimum taxes, rather than on their common features or such features' significance. This article aims to address this gap in the literature, drawing on my own more than thirty years of experience in thinking and writing about avowed minimum taxes, as well as provisions, such as foreign tax credit limitations, that turn out to be similar.

I conclude that minimum taxes have serious drawbacks, and generally make sense (if at all) only if otherwise superior options must be ruled out for reasons of optics or political economy. Yet, given the "compared to what?" question that haunts all real-world tax policymaking, one cannot reasonably say that they should never be used. Still, any such use should generally be contingent, reluctant, and based on understanding their structural deficiencies. 


\section{Minimum TAXEs HistoricAlly AND CONCEPTUALly}

The best-known minimum tax to date - the U.S. alternative minimum tax (AMT), in both its individual and corporate manifestations ${ }^{2}$ - was a key feature of the Tax Reform Act of $1986 .^{3}$ At the time, it was widely lauded (other than by tax reform purists) for its expected efficacy in preventing rich people and highly profitable corporations from unfairly, as it was thought, paying too little (and at the limit zero) in U.S. federal income taxes. ${ }^{4}$ Soon, however, the AMT began to attract widespread disparagement. ${ }^{5}$ In the 2017 U.S. tax act, the corporate AMT was repealed, and the individual AMT scaled back ${ }^{6}$-in each case to general, if not quite universal, approbation and relief. ${ }^{7}$

\footnotetext{
${ }^{2}$ I.R.C. $\S 55$ (2018) (establishing an individual minimum income tax); I.R.C. $§ 55$ (2012) (establishing a minimum income tax for both individuals and corporations). The corporate minimum tax was removed by the Tax Cuts and Jobs Act in 2017. Tax Cuts and Jobs Act, Pub. L. No. 115-97 § 12001, 131 Stat. 2054, 2092-93 (2017).

${ }^{3}$ Tax Reform Act of 1986, Pub. L. No. 99-514, 100 Stat. 2085 (1986).

${ }^{4}$ See e.g., Jeffrey H. Birnbaum \& Alan S. Murray, Showdown at Gucci Gulch: Lawmakers, LOBBYISTS, AND THE UNLIKELY TRIUMPH OF TAX REFORM 88 (1988).

${ }^{5}$ See e.g., Alternative Minimum Tax: Hearing Before the H. Subcomm. on Select Revenue Measures of the Comm. on Ways \& Means, 110th Cong. 1 (2007) (statement of Leonard E. Burman, Ph.D, Director, Tax Policy Center) ("The AMT doesn't do much to reign in tax shelters. Given the poor design, millionaires are actually less likely to owe AMT than middle income people with kids. It's inefficient, and it undermines support for the tax system because it's the poster child for pointless complexity."). For a popular discussion of the AMT at the time of the recent reform, see Patricia Cohen, A.M.T., With Few Defenders, Is Newly Targeted in Trump Tax Plan, N.Y. TIMES (Apr. 27, 2017), https://www.nytimes.com/2017/04/27/business/economy/trump-alternative-minimum-tax.html.
}

${ }^{6}$ Tax Cuts and Jobs Act $\S 12001$ (removing the corporate AMT and reducing the scope of the individual AMT). See also, Who Pays the AMT, TAX POL'Y CTR. (last visited Jan. 11, 2020), https://www.taxpolicycenter.org/briefing-book/who-pays-amt (discussing the changes to the AMT stemming from the TCJA).

${ }^{7}$ See e.g., Andrew Velarde, Keeping Corporate AMT Would Swallow Up Many Reform Benefits, TAX NoteS FED. (Dec. 5, 2017), https://www.taxnotes.com/tax-notes-today-federal/alternative-minimum-tax/keepingcorporate-amt-would-swallow-many-reform-benefits/2017/12/05/1xd0m (discussing the debate during the 2017 tax reform around whether the corporate AMT should be maintained); Richard Rubin, Rep. Kevin McCarthy Calls for Corporate AMT Repeal, Wall ST. J. (Dec. 4, 2017 9:57 A.M.) (describing Representative Kevin McCarthy's critique of the corporate AMT during the 2017 debate); Barbara Weltman, The Alternative Minimum Tax Is No More. Here's the 'But', INC. (Feb. 26, 2019), 
The 2017 act also, however, included two major international tax provisions with minimum tax structures, known colloquially as GILTI (for "global intangible low-taxed income") and the BEAT (for "base erosion anti-abuse" tax). ${ }^{8}$ Moreover, there has been much talk recently of enacting new types of minimum taxes, such as one based on large corporations' financial accounting statement or "book" income. ${ }^{9}$ So the AMT's sour historical playout over the last thirty-plus years does not seem to have rested on a consensus rejection of "minimum taxes" as such.

Meanwhile, in the international tax policy debate, global minimum taxes have attracted growing support from both scholars ${ }^{10}$ and policymakers. ${ }^{11}$ GILTI is such a tax in

https://www.inc.com/barbara-weltman/amt-corporate-alternative-minimum-tax-guide.html (discussing some of the drawbacks to the corporate AMT's repeal, such as uncertainty excess minimum tax credits).

${ }^{8}$ These were the base erosion and anti-avoidance tax (BEAT), I.R.C. § 59A (2018), and the global intangible low-taxed income rule (GILTI), I.R.C. § 951A (2018).

${ }^{9}$ See e.g., Victor Reklaitis, Biden Proposes Minimum Federal Tax Aimed at Amazon and Others Who Pay \$0, MARKETWATCh (Dec. 4, 2019 1:59 P.M.), https://www.marketwatch.com/story/biden-proposesminimum-federal-tax-aimed-at-amazon-and-others-who-pay-0-2019-12-04 (discussing Vice President Biden's campaign proposal to establish a new corporate minimum tax); c.f.; Elizabeth Warren, I'm Proposing a Big New Idea: The Real Corporate Profits Tax, Medium (Apr. 11 2019), https://medium.com/@teamwarren/im-proposing-a-big-new-idea-the-real-corporate-profits-tax-

29dde7c960d (proposing a supplemental seven percent tax on corporate profits in excess of one-hundred million dollars, rather than a minimum tax).

${ }^{10}$ See, e.g., Harry Grubert \& Rosanne Altshuler, Fixing the System: An Analysis of Alternative Proposals for the Reform of International Tax, 66 NAT'L TAX J. 671, 673 (2013) (supporting a global minimum tax applied to separately income generated for or within each country).

${ }^{11}$ GILTI is a global minimum tax. Kyle Pomerleau, What's up with Being GILTI?, TAX Foundation (Mar. 14, 2019), https://taxfoundation.org/gilti-2019. See also, e.g., Press Release, Sen. Max Baucus, S. Comm. on Fin., Baucus Unveils Proposals for International Tax Reform (Nov. 19, 2013), https://www.finance.senate.gov/chairmans-news/baucus-unveils-proposals-for-international-tax-reform (discussing taxing global profits at a fractional percentage of domestic rates); Eric Toder, Explaining the TCJA's International Reforms, TAX POL'y CTR. (Feb. 2, 2018), https://www.taxpolicycenter.org/taxvox/explaining-tcjas-international-reforms (discussing how "The TCJA follows the basic outlines of proposals introduced in recent years by leaders from both parties, including former House Ways and Means Committee Chair Dave Camp (R-MI), Senators Rob Portman (ROhio) and Charles Schumer (D-NY), and the Obama Administration"). 
the main, ${ }^{12}$ as is a recent proposal that the OECD included in "Pillar Two" of its ongoing global anti-base erosion (GloBE) initiative. ${ }^{13}$

Global minimum taxes differ from the domestic variety in that they compare two tax liability computations pertaining to the same tax base, rather than the taxes due on two alternative tax bases. The tax base for a global minimum tax is generally some version of the foreign source income (FSI) earned by resident multinational companies (MNCs). The foreign taxes paid on relevant FSI are compared the amount that would have been due in total under a specified global minimum tax rate (such as fifteen percent). If the former is less than the latter, the shortfall must be paid to the domestic sovereign, but an excess (such as paying more than fifteen percent abroad) does not trigger a refund from the sovereign to the MNC.

A country that imposes a global minimum tax thereby allows taxes paid to other countries to offset - dollar-for-dollar, in the pure case - the domestic liability that would otherwise have arisen, until such liability has declined to zero. In this regard, they draw on familiar domestic tax practice. For decades, countries that tax their residents' FSI have allowed foreign tax credits (FTCs) that reduce domestic tax liability, typically dollar-fordollar, ${ }^{14}$ by reason of the income taxes that have been paid to other sovereigns.

\footnotetext{
${ }^{12}$ Because GILTI allows only eighty and not one hundred percent foreign tax credits, it sits in the middle of the continuum between minimum taxes and separate instruments. See Part VI, infra.

13 OeCD, Public Consultation Document: Global Anti-Base Erosion Proposal (“Globe”)Pillar Two (2019) 6 (discussing a minimum tax as an element of Pillar Two).

${ }^{14}$ But see, I.R.C. $§ 960(d)(1)$ (2018) (limiting foreign tax credits available for GILTI to eighty percent of the actual foreign taxes paid); see also, KathleEn L. Ferrell, Chair, et Al., The NY STAte Bar Association-Tax Section, Comprehensive Reform of the U.S. InTERnational TAX System 18 (Jan. 23, 2018), https://www.nysba.org/WorkArea/DownloadAsset.aspx?id=79636 ("The policy rationale for the $80 \%$ haircut (and mismatched gross-up) has not been articulated. At odds with history - the FTC has been a dollar for dollar credit since it was enacted as part of the Revenue Act of 1918, almost 100 years ago").
} 
FTCs generally are allowed only subject to FTC limitations, ${ }^{15}$ which prevent their use to offset more than one hundred percent of the domestic tax that would otherwise be due with respect to the taxpayer's FSI. ${ }^{16}$ That is, they not only are nonrefundable, but also cannot be used to offset amounts due with respect to the taxpayer's domestic source income (DSI). They thereby bar domestic tax rates on FSI that are below zero (i.e., that are negative). Global minimum taxes replicate this feature of an FTC system, by not providing a refund if foreign taxes paid on FSI exceed the minimum rate.

A similar constraint applies with respect to taxable income generally, under the nearly universal income tax rule of loss nonrefundability, under which negative taxable income does not generate negative liability (i.e., a transfer from the government, computed at a positive tax rate). Due to loss nonrefundability, deductions can reduce current year tax liability to zero, but not below. ${ }^{17}$ So deductions cease to be currently useful at a certain point, based on overall ratios between them and gross income on the return. This is quite similar to how an AMT causes the ratio between the tax preferences that it identifies on the one hand, and regular taxable income on the other hand, suddenly to start curtailing the taxpayer's marginal benefit from the preferences.

\footnotetext{
${ }^{15}$ I.R.C. $\S \S 901(a), 904$ (date) (permitting FTCs not in excess of domestic liability per I.R.C. $§ 26(a)$ ).

${ }^{16}$ See FERRELL ET AL., supra note 14 (discussing how the GILTI FTC limitation is an exception to the general dollar-for-dollar creditability).

${ }^{17}$ Prior to the 2017 act, net operating loss carryovers, under I.R.C. $\S 172$, could be used to reduce current year taxable income to zero. However, the 2017 act provided that they cannot reduce it by more than 80 percent. Compare I.R.C. § 172(a) (2012) (permitting a deduction for "the aggregate of (1) the net operating loss carryovers to such year, plus (2) the net operating loss carrybacks to such year") with I.R.C. § 172(a)(2) (2018) (capping the available deduction to "80 percent of taxable income"). The 80 percent limitation was then temporarily suspended under Coronavirus Aid, Relief, and Economic Security Act of 2020, also known as the CARES Act.
} 
FTC limitations, global minimum taxes, and loss nonrefundability thereby all create a minimum domestic tax rate of zero on the swathes of income to which they apply. So do expressly "schedular" systems in which the taxes due on different types of income are computed separately, and nonrefundability applies to each. All such systems naturally invite comparison to, say, a twenty percent AMT's barring tax rates below twenty percent on alternative minimum taxable income (AMTI). As we will see, partly for semantic reasons, such comparisons are rarely made.

Even this short summary should suffice to raise a number of puzzling questions about minimum taxes that warrant scrutiny. They include at least the following:

1) What does it mean for something to be (or to be called) a minimum tax? What substantive, technical, or merely semantic features might affect the use of this term?

2) Insofar as the "minimum tax" label is meaningful, why is its appeal to various audiences so divergent and so apparently volatile?

3) When is a minimum tax a good idea? Are particular types of design constraints needed for it to emerge as plausibly the best available option?

4) How similar or different are domestic minimum taxes both from loss nonrefundability, and from income tax rules that limit particular tax benefits (such as deductions) in relation to a specified income measure? ${ }^{18}$

5) How similar or different are global minimum taxes from both domestic minimum taxes, and FTCs that are subject to FTC limitations?

\footnotetext{
${ }^{18}$ See, e.g., I.R.C. § 163(j) (2018) (limiting deductions for business interest to thirty percent of "adjusted taxable income"); I.R.C. § 172(a)(2) (2018) (limiting net operating loss deductions to, at most, eighty percent of taxable income, as computed without regard to the net operating loss deduction). The CARES act temporarily changed the operation of both provisions. A number of other, more longstanding, rules have also limited particular deductions in relation to adjusted gross income. See, e.g., I.R.C. § 170(b) (restricting certain charitable deductions to specified percentages of what is generally adjusted gross income).
} 
To address such questions, one must start by defining one's terms. In this paper, three main definitions and concepts will guide the discussion:

1) Purposive definition of a minimum tax: Historically, minimum taxes have generally been an income tax instrument. This reflects that income, as a measure, uses an annual perspective to judge ability to pay (or whatever one calls one's vertical ranking metric). ${ }^{19}$ Minimum tax proponents view the annual perspective as suggesting that it is important, as a matter of actual or perceived equity, that high-income individuals and/or highly profitable corporations each year pay taxes that equal at least some minimum percentage of their incomes for that year. To quote the legislative history of the 1986 Act:

Congress concluded that the minimum tax should serve one overriding objective: to ensure that no taxpayer with substantial economic income can avoid significant tax liability by using exclusions, deductions, and credits. Although these provisions may provide incentives for worthy goals, they become counterproductive when taxpayers are allowed to use them to avoid virtually all tax liability. The ability of high-income taxpayers to pay little or no tax undermines respect for the entire tax system and, thus, for the incentive provisions themselves. In addition, even aside from public perceptions, Congress concluded that it is inherently unfair for high-income taxpayers to pay little or no tax due to their ability to utilize tax preferences. ${ }^{20}$

Accordingly, a minimum tax in the purposive sense is characterized by its aiming to require - especially, or perhaps even exclusively, from "high-income taxpayers" - the current year payment of at least some minimum percentage of economic income that might not otherwise be due under otherwise applicable income tax rules (i.e., under the "regular tax"). This implies the presence of underlying beliefs that (1) economic income is

\footnotetext{
${ }^{19}$ Consumption taxes, by contrast, take a lifetime perspective. See, e.g., Daniel Shaviro, Beyond the ProConsumption Tax Consensus, 60 StAN. L. ReV. 745, 748 (2007).

${ }^{20}$ Staff of the Joint Comm. on TAXation, General Explanation of the Tax Reform Act of 1986 432-33 (Comm. Print 1987) (henceforth “JCT, 1986 General Explanation”).
} 
normatively important to the proper distribution of current year tax burdens, and (2) such importance rises more than ratably as economic income rises.

Under global minimum taxes, this involves looking directly at the foreign taxes paid on some measure of FSI. But otherwise, achieving this aim requires that the minimum tax have what I will call a "broader" base than the regular tax, albeit accompanied by a lower statutory tax rate. I use "broader," however, not just as an arithmetic statement about the relative sizes of the two tax bases, like "larger." Rather, I define "broader," in contrast to "larger," as additionally requiring that the expanded base be closer to economic income. This usage reflects that the minimum tax's purposive definition involves setting a floor on current year tax liability relative to economic income. If a minimum tax denies deductions that the regular tax system allows, then, these items should be - which is not to say that, in practice, they always are - preferential, as judged from an income tax standpoint.

Suppose that a secondary, alternative tax base denied all deductions for the costs of earning income, and hence taxed gross, rather than net, income, albeit at a lower rate than the regular tax. Under the above vocabulary, the base of the alternative tax would indeed be "larger" than that under the regular tax, but it would not properly qualify as being "broader." It thus would fail to be a minimum tax purposively, except insofar as one could reasonably argue that, in practice, the allowable regular tax deductions so exceeded those that would properly be allowable under a true net income measure as to suggest that gross income might actually come closer to measuring it accurately. ${ }^{21}$

\footnotetext{
${ }^{21}$ In practice, it may be disputed whether a given deduction is appropriate from an income measurement standpoint for tax items such as state and local taxes. See e.g., DEP'T OF TREASURY, TAX REFORM FOR FAIRNESS, SIMPLICITY, AND ECONOMIC GROWTH 78 (1984) (stating, controversially, that a federal deduction for state and local income taxes paid is "not required for the accurate measurement of income.").
} 
In this regard, consider the BEAT, a technical minimum tax (as defined below) that Congress enacted in 2017. ${ }^{22}$ It requires certain MNCs to pay the greater of (a) the regular corporate tax, computed at the generally applicable twenty-one percent rate, and (b) the BEAT itself, computed at a ten percent effective rate but after adding back all deductible payments that the taxpayer made to foreign affiliates. ${ }^{23}$ All else equal, this results in overmeasuring the U.S. affiliate's economic income, unless the proper deduction for these items would have been zero.

One can still call the BEAT a minimum tax if one likes (and it often is so called). Moreover, it does, evidently reflect concern that deductible payments to foreign affiliates may lead to under-measurement of MNCs' true U.S.-source economic income. Yet, given the BEAT's clear over-reaching in this regard, it seems likely that, even among its strongest proponents, few are likely to be so bullish about it as to favor its wholly replacing the regular tax, and/or its having more than a low marginal rate. By contrast, in the 1980s there were AMT proponents who urged that it wholly replace the regular tax. ${ }^{24}$ This aspect alerts us to the possibility that, even if one deems the BEAT's overreaching justifiable on balance, one may still rationalize it quite differently than AMT proponents rationalized the AMT during its heyday.

2) Technical definition of a minimum tax: A fully specified tax typically determines the amount that one owes, given the application of its rate(s) to its base. Under what I will

\footnotetext{
${ }^{22}$ I.R.C. $\S 59$ A.

${ }^{23}$ I.R.C. § 59A(b)(1) (defining the "base erosion minimum tax" amount to be the excess of ten percent of the BEAT's base over the regular tax liability under I.R.C $\S 26(b))$.

${ }^{24}$ See, e.g., Michael J. Graetz, The 1982 Minimum Tax Amendments as a First Step in the Transition to a "Flat-Rate" Tax, 56 S. CAL. L. REV. 527 (1983).
} 
call a "technical" minimum tax, however, one need not pay the amount thus determined in all events. Rather, minimum tax liability is due only if, and to the extent that, it exceeds the amount of regular tax that one would otherwise pay.

For example, suppose one would pay $\$ 100 \mathrm{X}$ if the minimum tax always applied. Since it is a minimum tax, however, this amount is compared to liability under the regular tax (or to foreign tax liability, under a global minimum tax). Suppose that one's regular tax liability is either (a) $\$ 80 \mathrm{X}$ or (b) $\$ 120 \mathrm{X}$. The minimum tax requires paying an extra $\$ 20 \mathrm{X}$ in case (a), but offers no refund of the "excess" regular tax liability in case (b). ${ }^{25}$ Refundability must be ruled out because it would cause minimum tax liability to determine the taxpayer's overall liability in all cases - in contrast to the actual scenario, in which one's net liability equals whichever is the greater of the two.

Looking at the relationship between the two tax bases in terms of creditability permits one to see how intermediate cases can arise. For example, suppose that, in the above hypothetical, regular tax liability was only 80 percent creditable, rather than 100 percent creditable, against minimum tax liability. Then, in the case where regular tax liability was $\$ 120$, only $\$ 96 \mathrm{X}$ would be creditable against the minimum tax, causing liability under the latter to be $\$ 4 \mathrm{X}$, rather than zero.

For that matter, merely allowing regular taxes to be deducted under a minimum tax with a 20 percent rate would be arithmetically equivalent to denying any such deduction but offering 20 percent creditability for one's regular tax liability. Likewise, suppose that

\footnotetext{
${ }^{25}$ It would be arithmetically equivalent to say that one pays whichever of the two tax liabilities is greater. Or one could say that both taxes are due, but that the regular tax liability is one hundred percent creditable, albeit nonrefundably, against the minimum tax liability (or vice versa). However, minimum taxes' purposive character supports viewing them as adjusting a prior regular tax result.
} 
regular tax liability was nondeductible, but even just 1 percent creditable against minimum tax liability. Thus, for example, a $\$ 120 \mathrm{X}$ liability under the "regular tax" (if one so called it) would cause a $\$ 100 \mathrm{X}$ pre-credit liability under the "minimum tax" to decline to $\$ 98.80 \mathrm{X}$ post-credit. Practically speaking, this would not be much different from offering no credit, and thereby causing the two systems to apply entirely independently of each other.

Such examples help to show that, in principle, the question of whether something is more of a minimum tax, or more of a separate and supplemental tax, is merely a question of degree along a continuum. However, real world examples are often sufficiently bimodal to permit one's drawing crisp distinctions between the two types of instruments.

To further illustrate the distinction between minimum taxes and stand-alone instruments, consider two recent tax proposals from the early stages of the 2020 Democratic primary campaign. Vice President Biden proposed a fifteen percent corporate minimum tax based on book income, which would be payable only if, and to the extent that, the tax liability that it determined exceeded that being paid by the taxpayer under the regular corporate tax. ${ }^{26}$ By contrast, Senator Warren proposed a seven percent tax on large U.S. companies' book income that would be payable in any event, i.e., without regard to the taxpayer's regular tax liability. ${ }^{27}$ This would simply be a separate and supplementary

\footnotetext{
${ }^{26}$ See Kyle Pomerleau, Joe Biden Wants to Reintroduce a Corporate Minimum Tax, AM. ECon. InST. (Dec. 4, 2019), https://www.aei.org/economics/joe-biden-wants-to-reintroduce-a-corporate-minimum-tax ("The minimum tax would be 15 percent of book profits, but would still allow a deduction for losses carried forward from previous years and a credit for foreign taxes paid. As a minimum tax, a company would ... pay tax to the extent that the minimum tax liability exceeds normal liability.").

${ }^{27}$ Warren, supra note 9 (describing Warren's corporate tax proposal). However, past years' regular taxes, along with book income taxes, would be implicitly deductible under the Warren add-on instrument, causing them to resemble seven percent credits, if liability was based on an after-federal-tax measure of financial accounting income.
} 
tax, applying alongside the corporate income tax just as individuals pay both federal income and federal payroll taxes. ${ }^{28}$

3) Further semantic boundaries of the minimum tax concept: Consider again the operation of an international tax regime in which FSI is taxed, subject to allowing FTCs with FTC limitations. Under U.S. law prior to the 2017 tax act, this meant that U.S. MNCs' FSI, when includable in U.S. taxable income, faced minimum tax rates of thirty-five percent globally, and zero percent domestically.

In neither respect, however, was the U.S. international tax regime commonly described as involving a "minimum tax." On the global side, this may simply have reflected that the U.S. worldwide rate had not historically arisen as part of a cooperative global effort to ensure that MNCs, U.S. or otherwise, were paying enough tax somewhere. Rather, it had grown out of early U.S. decisions to tax residents' FSI at the same rate as their DSI, but then also to allay "double taxation" (at first unilaterally) via FTCs, apparently on the view that not doing so would be unfair to the double-taxed. ${ }^{29}$ The subjective focus was thus more solipsistically national—asking what we should do to our companies, albeit taking as given what other countries do - than aimed at establishing a particular global regime in the manner of today's global minimum tax proposals. ${ }^{30}$

\footnotetext{
${ }^{28}$ While the regular personal income and payroll taxes are otherwise separate, the former could be viewed as implicitly deducting the employer's share of the latter, since that share is not included in the employee's wage income. See generally John Olson, What Are Payroll Taxes and Who Pays Them?, TAx Foundation (July 25, 2016), https://taxfoundation.org/what-are-payroll-taxes-and-who-pays-them (describing the payroll tax system and its interplay with the personal income tax).

${ }^{29}$ See Michael J. Graetz \& Michael M. O'Hear, The "Original Intent" of U.S. International Taxation, 46 DUKE L.J. 1021, 1033-41 (1997) (discussing the historic rationale for the United States's adoption of a FTC system).

${ }^{30}$ On the aims underlying contemporary global minimum tax proposals, see, e.g., Aaron Junge et al., Design Choices for Unilateral and Multilateral Foreign Minimum Taxes, TAX Notes FeD., Sept. 2, 2019 at 1525, https://www.taxnotes.com/tax-notes-today-federal/international-taxation/design-choices-unilateral-and-
} 
But what about the zero percent minimum domestic rate on FSI that results from applying FTC limitations? Its exclusion from the family of purposive "minimum taxes" becomes less surprising when one considers the semantics of popular or lay arithmetic. Suppose that-unlike a mathematician or a well-trained economist-one thinks asymmetrically and discontinuously about positive numbers, as compared to zero and negative numbers. Then disallowing negative tax rates for FSI, or denying net refunds under loss nonrefundability, may seem so automatic and inevitable a tax system feature that it disappears into the landscape. One may fail to realize that zero is a discretionary minimum rate or amount, like any other. By contrast, the enactment of an AMT, requiring that AMTI be taxed at some minimum positive, rate, plainly represents an exercise of discretionary choice. The similarities between the two types of rules are therefore readily overlooked, and the "minimum tax" label reserved for requiring rates above zero.

With these definitions in place, this Article now turns to two of the two main puzzles presented by minimum taxes. The first one applies to them all, while the second only applies to global minimum taxes:

1) Why have two interacting tax bases?: According to local lore that I heard years ago at the University of Chicago Law School, the popular author Mortimer Adler once gave a lecture there concerning his book Six Proofs of the Existence of God. After Adler

multilateral-foreign-minimum-taxes/2019/09/17/29vng (noting that they aim to limit MNCs' profit-shifting, allay perceived harmful tax competition, and increase corporate tax collections). 
had finished explaining the first proof, a skeptic in the audience raised his hand and asked: "If the first proof was so good, why do you need the other five?"31

A version of this question applies to using a minimum tax to supplement the regular tax by applying conditionally, based on the relative tax liabilities that the two systems yield. If the regular tax is worth retaining, why backstop it with the minimum tax? If both are independently valuable, why not apply each separately? After all, in that scenario their rates could be reduced so as to keep overall revenues the same. ${ }^{32}$

The point here is not just that a fiscal system that includes both regular and minimum taxes has multiple "tax systems" employing distinctive tax bases. Doing that is wholly routine. ${ }^{33}$ However, insofar as such tax systems operate independently of each other, one could view them (substantively, even if not administratively), as complementary components of a single more broadly defined "tax system" that merely happens to address multiple taxpayer attributes and margins. ${ }^{34}$ The use of both regular and minimum taxes adds a separate element of interdependent applicability. Causing amounts due under one system to depend on amounts due under the other not only seems perplexing in and of

\footnotetext{
${ }^{31}$ Daniel Shaviro, Making Sense of Social Security Reform 89 (2000).

${ }^{32}$ Similarly, the repeal of FTC limitations and nonrefundability could be accompanied by commensurately raising positive tax rates, such that aggregate revenues remained the same. Here, in effect, the extra system is eliminated, rather than made freestanding, given that its tax base is the same.

${ }^{33}$ For examples of multiple tax bases that operate (at least largely) separately from each other, consider the U.S. income and payroll taxes, or other countries' income taxes and value-added taxes (VATs).

${ }^{34}$ For a broader defense of separately deploying multiple tax bases in this sense, see David Gamage, How Should Governments Promote Distributive Justice: A Framework for Analyzing the Optimal Choice of Tax Instruments, 68 TAX L. REV. 1, 27-29 (2014) (discussing the complementary use of multiple tax bases).
} 
itself, but creates distinctions that may be hard to rationalize with regard to which of them applies at the margin to a particular taxpayer. ${ }^{35}$

To illustrate the issues that such interdependence raises, suppose that a particular interest deduction is allowable under the regular tax, with a hypothetical 30 percent rate, but not under the minimum tax, with a hypothetical 20 percent rate. For a taxpayer whose regular tax liability exceeds her minimum tax liability (i.e., who is "on the regular tax"), incurring a $\$ 1$ interest deduction reduces her tax liability by 30 cents, thereby reducing her after-tax interest cost to 70 cents. By contrast, for one whose minimum tax liability exceeds her regular tax liability (i.e., who is "on the minimum tax"), the outlay has no effect on liability, and costs her the full $\$ 1$ after-tax. This may cause taxpayers that are competing with each other to face distinct economic incentives (or disincentives) at particular margins. ${ }^{36}$ It also (depending on further design details) may require taxpayers not just to compute liability and keep records (such as the basis of assets) under multiple systems, but also to plan for the systems' interactions, as this will affect both overall liability and marginal incentives.

\footnotetext{
${ }^{35}$ In some states' corporate income taxes (often styled as franchise taxes), alternative bases may be used, but apparently reflecting a different history and set of rationales. For example, under Article 9A of New York State's franchise tax on general business corporations, one owes the highest tax due under three bases: business income, business capital, and a so-called fixed dollar minimum tax that relies on gross receipts. One possible reason for thus using alternative tax bases may be to reduce the volatility of states' corporate tax revenues. See, e.g., Garrett Watson, Resisting the Allure of Gross Receipts Taxes: An Assessment of Their Costs and Consequences. Tax Foundation, February 2019, available online at https://files.taxfoundation.org/20190205153928/Resisting-the-Allure-of-Gross-Receipts-Taxes-AnAssesment-of-Their-Costs-and-Consequences.pdf .

${ }^{36}$ This also happens within a single tax instrument when taxpayers face non-uniform, such as progressively graduated, marginal tax rates. For an empirical discussion of the distortive effects of progressive marginal effects, see Spencer Bastania \& Håkan Selin, Bunching and Non-Bunching at Kink Points of the Swedish Tax Schedule, 109 J. PuB. ECON. 36 (2014); Daniel le Maire \& Bertel Schjerning, Tax Bunching, Income Shifting, and Self-Employment, 107 J. PUB. ECON 1 (2013); Bruce Chapman \& Andrew Leigh, Do Very High Tax Rates Induce Bunching? Implications for the Design of Income Contingent Loan Schemes, 85 ECON. RECORD 276 (2009); Jacob A. Mortenson \& Andrew Whitten, How Sensitive Are Taxpayers to Marginal Tax Rates Evidence from Income Bunching in the United States (Working Paper, Jan. 2016).
} 
Worldwide tax systems with foreign tax credits, reflecting their economic resemblance to avowed minimum taxes despite the semantics of the number zero, offer a well-known example. Under the pre-2017 U.S. system, some U.S. MNCs were "excesscredit." 37 That is, they had already zeroed out their U.S. tax liability on FSI through the use of foreign tax credits, and thus could not (at least currently) make any further marginal use of credits. A $\$ 1$ increase in their foreign tax liabilities would therefore cost them the same $\$ 1$ after U.S. tax as before. By contrast, other MNCs were "excess limit" or "deficitcredit." 38 That is, they could still currently use additional foreign tax credits at the margin. In consequence, a $\$ 1$ increase in their foreign tax liabilities would cost them zero after U.S. tax, eliminating any economic incentive for them to be cost-conscious with respect to such liabilities. ${ }^{39}$ This raised the question, not only of why one would treat the latter group's foreign tax liabilities so generously, but also of why one would create two MNC subclasses or clienteles, facing distinct marginal incentives that might, for example, differentially distort their locational and asset choices. ${ }^{40}$ It also required MNCs whose status might flip

\footnotetext{
${ }^{37}$ See Harry Grubert, Tax Planning by Companies and Tax Competition by Governments: Is There Evidence of Changes in Behavior? 114-17, in InTERNATIONAL TAXATION AND MultinATIONAL ACTIVITY (James R. Hines Jr. ed., 2001) (discussing MNCs with excess credits); see also Julie H. Collins et al., Valuing Deferral: The Effect of Permanently Reinvested Foreign Earnings on Stock Prices 143, in InTERNATIONAL TAXATION and MultinAtional Activity (James R. Hines Jr. ed., 2001).

${ }^{38}$ See Collins et al., supra note 37 (discussing excess limit and credit deficit MNCs).

${ }^{39}$ See e.g., Kimberly Clausing \& Daniel Shaviro, A Burden-Neutral Shift from Foreign Tax Credibility to Deductibility, 64 TAX L. REV. 431, 432-435 (2011) (discussing the problem that deficit-credit MNCs do not have "cost-consciousness" with respect to marginally more foreign taxes).

${ }^{40}$ See e.g., Grubert, supra note 37 (discussing the distortive effect that FTCs have on firms' asset and location choices); see also Harry Grubert \& Rosanne Altshuler, Corporate Taxes in the World Economy: Reforming the Taxation of Cross-Border Income 1, 9-10 (Working Paper, Dec. 12, 2006), http://citeseerx.ist.psu.edu/viewdoc/download?doi=10.1.1.575.2971\&rep=rep1\&type=pdf (discussing how FTCs impact "the various behavioral decisions ... such as the location of income and its repatriation").
} 
between the two categories to address tax planning and compliance issues associated with the discontinuity. ${ }^{41}$

As we will see, there are nonetheless various arguments that can be made in favor of a minimum tax structure. Often, they rely on claimed optical and political economy advantages of such a structure, rather than on direct economic rationales for employing it. In some cases, however, it can be argued that the differences between tax base amounts as computed under the regular and minimum tax systems is itself probative with regard to some metric of interest, such as "true" economic income. For example, suppose that a company's having financial accounting income far in excess of its taxable income suggests that the latter is substantially (and undesirably) less than its economic income. This might, for example, be deemed likely to have resulted from the company's engaging in unusually aggressive tax planning. ${ }^{42}$ In that scenario, interacting the two systems, rather than having them operate entirely separately, might have informational value with respect to measuring (and duly taxing) economic income. However, the interaction between the systems that one chooses for informational reasons turns out not to require using a minimum tax structure.

2) Why have global minimum taxes in particular?: Global minimum taxes raise the further question of why a sovereign would allow taxes paid to other sovereigns to offset its

\footnotetext{
${ }^{41}$ See Grubert \& Altshuler, supra note 40 at 9-10 (explaining how “[e]ach of these 'unseen' positive and negative components (income shifting, allocations, tax planning costs) is an important consideration" in the discussion of FTCs and tax planning); Edward D. Kleinbard, Throw Territorial Taxation from the Train, TAX Notes, Feb. 5, 2007 at 547, 554-55.

${ }^{42}$ See e.g., Mihir A. Desai, The Divergence Between Book and Tax Income, 17 TAX \& POL. ECON. 169, 200 (2003) ("The large discrepancy reported between simulated book income and actual book income ... suggest[] that efforts by firms to circumvent tax payments are becoming more significant, cheaper to implement, and harder to detect."); see also Christopher S. Armstrong et al., The Incentives for Tax Planning, 53 J. ACCT. \& ECON. 391 (2012) (empirically examining corporate tax planning strategies and incentives, which may cause divergence of tax and book value); Mihir A. Desai \& Dhammika Dharmapala, Corporate Tax Avoidance and High-Powered Incentives, 79 J. FIN. ECON 145 (2006) (examining the incentives of corporate managers to use tax planning strategies to create book-tax divergences).
} 
own tax claims. Moreover, while only one hundred percent creditability wholly eliminates resident MNCs' cost-consciousness with regard to foreign taxes, the question of how foreign taxes should affect domestic liability is more general. ${ }^{43}$ In past work, I have called this the question of what marginal reimbursement rate (MRR) should apply domestically to foreign taxes. ${ }^{44}$ As we will see, a domestic policymaker's response to this question may depend partly on whose wellbeing she considers normatively relevant in particular, given the widely followed distinction between "us" and "them" (or residents / citizens and those who are considered foreigners $).{ }^{45} \mathrm{~A}$ view that national policymakers tend to treat their own residents' or citizens' welfare as far more policy-relevant than that of outsiders has strong purchase as a descriptive matter, whether or not one considers it morally defensible. ${ }^{46}$

Even if one presumes that national welfare (defined in terms of "us" as distinct from "them") is the relevant lodestar, a further issue that is highly relevant to the choice of MRR,

\footnotetext{
${ }^{43}$ See generally Clausing \& Shaviro, supra note 39 (discussing the interplay of FTCs with domestic liability).

${ }^{44}$ Daniel N. Shaviro, Rethinking Foreign Tax Creditability, 63 NAT’L TAX J. 709, 709 (2010) (“[E]xperts often mistakenly conflate two distinct margins: (1) the overall tax burden on outbound investment, and (2) the marginal reimbursement rate (MRR) for foreign taxes paid, which is 100 percent under a foreign tax credit system, but equals the marginal tax rate for foreign source income under ... deductibility system ...."); Daniel Shaviro, The Case Against Foreign Tax Credits, 3 J. Legal AnALYsIs 65, 65 (2011) ("[T] he incentive problems resulting from a 100 percent MRR for foreign taxes paid may illuminate various more practical tax issues, such as the merits of (1) shifting to an exemption system, which features implicit deductibility, and (2) various proposed reforms, such as removing disincentives . . . tax planning by U.S. multinationals."); Clausing \& Shaviro, supra note 39.
}

${ }^{45}$ See Daniel Shaviro, Taxing Potential Community Members' Foreign Source Income 1 (N.Y.U. L. \& Econ., Research Paper No. 15-09, 2015) (discussing the distinction "between people whom we classify as members of the home community, and thus whose welfare we care about, and those whom we classify as normatively irrelevant (or less relevant) outsiders.")

${ }^{46}$ See e.g., Wojciech Kopczuk et al., The Limitations of Decentralized World Redistribution: An Optimal Taxation Approach, 49 EUROPEAN ECON. REV. 1051 (2005) (estimating that the United States implicitly considers the welfare of a foreigner to be only $1 / 2000^{\text {th }}$ as valuable as welfare to a United States citizen). This choice to privilege a nation's own residents has been often critiqued. See e.g., John Rawls, The Law of Peoples, 20 Critical InQuiry 36, 38 (1993) (discussing the obligation that any conception of justice must extend to all people, otherwise be judged lest "a liberal conception of political justice would appear to be historicist and to apply only to societies whose political institutions and culture are liberal."). 
and more generally to how one views the payment of taxes by one's residents to foreign sovereigns, concerns the distinction between what I call unilateral and strategic perspectives. I define a country as acting unilaterally if (or insofar as) its policymakers assume that other countries' choices, in international tax policy or otherwise, are entirely independent of its own. ${ }^{47}$ By contrast, I define a country as acting strategically if (or insofar as) its decisions take into account the question of how its actions will affect what other countries subsequently do. ${ }^{48}$ As we will see, the choice of MRR has multiple dimensions, and no clear answer, even in a unilateral framework, and a strategic one can add substantial further complications.

The remainder of this Article proceeds as follows. Part II examines the individual and corporate AMTs that were enacted in 1986. Part III considers the choice between minimum tax and freestanding approaches to taxing companies financial accounting income. Part IV discusses the BEAT. Part V examines loss nonrefundability and FTC limitations (taking as given, for this purpose, the allowance of FTCs otherwise). Part VI considers the treatment of foreign tax liabilities by foreign tax credit systems and global minimum taxes. A brief conclusion then discusses general lessons to be learned.

\footnotetext{
${ }^{47}$ Game theory literature often calls this acting "naively," rather than unilaterally, but I prefer to use a more neutral-sounding term, for the benefit of readers who are not immersed in that literature. See e.g., Jordi Brandts \& Charles A. Holt, Naïve Bayesian Learning and Adjustment to Equilibrium in Signaling Games, 3 J. ECON. BEHAV. \& ORG. 164 (1996).

${ }^{48}$ The choice of a strategic perspective need not depend on believing that policymakers in other countries are deliberately acting strategically. All that matters is that their future decisions might be affected in some way by one's own.
} 


\section{The 1986 Alternative Minimum TaX}

\section{A. From "Just One Cent" to a Preference Rationing Rule}

The modern AMT, which dates from $1986^{49}$ (although it was repealed for corporations in $2017^{50}$ ), applies a lower rate than the regular tax to what is meant to be a broader base. ${ }^{51}$ Its avowed goal was to permit Congress, despite deliberately retaining various items that might be preferential from an income measurement standpoint, to "ensure that no taxpayer with substantial economic income [could] avoid significant tax liability" through their use. ${ }^{52}$ This concern reflected the importance that policymakers attached in 1986 to "mak[ing] certain [that newspaper] stories about millionaires and corporations escaping all taxes never surfaced again." 53 The salience of such taxpayers' paying no tax, rather than very little, briefly gave some of Washington's more cynical

\footnotetext{
49 Tax Reform Act of 1986, Pub. L. No. 99-514, 100 Stat. 2085 (1986). Prior to the 1986 Act, corporations were subject to what was called an add-on minimum tax, while individuals were subject to a more limited alternative minimum tax. See JCT, 1986 General Explanation, at 429-432. For a contemporary discussion of the AMT, see Daniel Shaviro, Perception, Reality and Strategy: The New Alternative Minimum Tax, TAXES, Feb. 1988, at 91-92 \& n. 9 (discussing the 1986 Act and the pre-1986 AMT).

${ }^{50}$ Tax Cuts and Jobs Act, Pub. L. No. 115-97 § 12001, 131 Stat. 2054, 2092-93 (2017).

${ }^{51}$ See Scott Eastman, The Alternative Minimum Tax Still Burdens Taxpayers with Compliance Costs, TAX FOUNDATION (Apr. 4, 2019), https://taxfoundation.org/alternative-minimum-tax-burden-compliance (discussing the AMT's "broader base"); Shaviro, supra note 45 at 92-93 ("The minimum tax, applying to a broader income base than the regular tax (generally, regular taxable income plus specified preferences), but at a lower rate ...."); but see Greg LeISERSON \& JeFFrey Rohaly, URBAN-BroOKINGS TAX POL'y CTR., The Individual Alternative Minimum Tax: Historical Data and Projections 6 (Nov. 2006) (disagreeing with the standard wisdom that the AMT taxes a larger base in practice, if not in theory). Even if the minimum tax base is broader than the regular tax base, it can yield a smaller income measure in a particular year-for example, due to timing differences. Also, note that larger AMT than regular tax exemption amounts are best thought of as effectively a zero bracket rather than as an aspect of tax base breadth.

${ }^{52}$ H.R. REP. No. 99-426 at 305-06 (1985).

${ }^{53}$ BirnBAUM \& MURRAY, supra note 4 at 88.
} 
policymakers the hope that it might suffice if all were required to pay at least one dollar, ${ }^{54}$ or perhaps even - as I recall Senator Russell Long saying, during a Senate Finance Committee markup that I attended in 1986 as a Capitol Hill staffer- “just one cent.”

However, the actual AMTs that emerged from the 1986 Act were much more substantial than this: The individual AMT generally applied a 21 percent rate (over an exemption amount), as compared to a 28 percent top rate bracket under the regular tax. ${ }^{55}$ The corporate AMT had a 20 percent rate, as compared to 34 percent in the regular tax. ${ }^{56}$ The AMTs also were expected to raise significant revenue - a projected $\$ 22$ billion over the 1986 Act's first five years on the books. ${ }^{57}$ Thus, rather than aiming for "just one cent" for high-income individual and large corporations, the post-1986 AMTs pushed towards more generally rationing the use of specified tax preferences relative to taxable income.

To illustrate such rationing at a simple conceptual level, suppose the following:

1) The regular tax has a 30 percent flat rate, while the AMT has a 20 percent flat rate.

2) Asset A earns a 10 percent annual pre-tax return. This return is fully included in both regular taxable income and AMTI.

\footnotetext{
${ }^{54}$ See id. at 88 (referencing Treasury Secretary James Baker's brief consideration of such a proposal).

${ }^{55}$ I.R.C. § 55(b)(1) (2018); see also Shaviro, supra note 45 at 95.

${ }^{56}$ I.R.C. $\S 55(\mathrm{~b})(1)$ (2018); see also Shaviro, supra note 45 at $111 \&$ n. 128 (discussing the $20 \%$ corporate AMT rate); Lowell Dworin, Impact of the Corporate Alternative Minimum Tax, 40 NAT'L TAX J. 505, 507 (1987) (discussing the twenty percent corporate rate).

${ }^{57}$ Dworin, supra note 56 at 505 (discussing Joint Committee on Taxation estimates that the corporate AMT would raise twenty-two billion dollars in revenue between 1987 and 1991).
} 
3) Asset B earns an 8 percent annual pre-tax return. ${ }^{58}$ This return is exempt from regular taxable income, but is included in AMTI.

4) Acme Products, a price taking U.S. company, has a fixed $\$ 100 X$ to invest in some combination of Assets A and B. Acme's only concern is maximizing after-tax returns (without regard, for example, to diversification or risk). It anticipates having no taxable income or losses other than from so investing the \$100X. (However, I will note below the possible significance of relaxing both this assumption and that of its having fixed capital to invest).

Absent the AMT, Acme would only hold tax-favored Asset B, perhaps leading to inflammatory newspaper stories about its resulting $\$ 8 \mathrm{X}$ of wholly untaxed income (if $\mathrm{X}$ adds enough zeros to the stated numeral). With the AMT, however, this becomes a suboptimal choice. So long as Acme is on the AMT at the margin (which is the case until it has shifted $\$ 61.5 \mathrm{X}$ of its investment from Asset B to Asset A), ${ }^{59}$ Asset $\mathrm{A}$ is more appealing, as it offers an 8 percent, rather than 6.4 percent, after-tax return under the relevant instrument. However, as soon as Acme shifts to being on the regular tax at the margin, Asset B resumes its status as the more appealing after-tax asset (8 percent versus 7 percent).

\footnotetext{
${ }^{58}$ For purposes of the example, I propose simply to assume that this is a stable equilibrium, at least in the short run. Obviously, a fully realistic example would require considering tax capitalization, risk differences, the elasticity of attributes needed to enable capacity to use the assets effectively, and so forth.

${ }^{59}$ Letting XA denote the amount of income investment in asset $\mathrm{A}$, the regular tax burden is: Tax $x_{\text {Regular }}=$ $X_{A} \cdot 10 \% \cdot 30 \%$, where the return on investment in asset $\mathrm{A}$ is $10 \%$ and the tax $30 \%$. The alternative minimum tax burden is then: $\operatorname{Tax}_{\text {Minimum }}=\left(X_{A} \cdot 10 \%+\left(100-X_{A}\right) \cdot 8 \%\right) \cdot 20 \%$, where the return on asset B is $8 \%$ and the tax rate is $20 \%$. As such, so long as $X_{A} \leq \frac{8}{13} \approx 0.615$, then the regular tax obligation will be less than the minimum tax obligation.
} 
Just within the corners of this toy hypothetical, this means that Acme, rather than investing its entire \$100X in Asset B, will invest \$61.5X in Asset A and \$38.5X in Asset B. ${ }^{60}$ Thus, if there were no more to the story, the AMT would seemingly have reduced investment in tax-favored Asset B relative to fully taxable Asset A. This might increase economic efficiency, at the particular margin of asset choice, given A's higher pre-tax return. However, once we embed the hypothetical in a more realistic broader setting, a number of objections and caveats emerge, including at least the following:

1) We don't know enough about the broader equilibrium to specify the effect on aggregate overall investment in Assets A versus B (or other alternatives). Indeed, even if overall investment in Assets A plus B is fixed, it is conceivable that, at least to a significant extent, ownership of Assets A and B will merely end up being reshuffled between firms.

2) The above possibility raises the concern that disparities between firms that, at the margin, are on the regular tax versus the AMT may end up inefficiently distorting asset ownership patterns as to Assets A and B. In effect, firms now divided into two clienteles, depending on whether they face the regular tax or the AMT at the margin.

3) Further choice margins that may affect efficiency pertain to possible changes in Acme's investment capital, and its hitherto assumed lack of other taxable income and loss. For example, while nothing has been said about Acme's

\footnotetext{
${ }^{60}$ The optimality of investing $\$ 61.5 \mathrm{X}$ in Asset A and $\$ 38.5 \mathrm{X}$ in Asset B can be seen intuitively. If less than $\$ 61.5 \mathrm{X}$ were invested in Asset A, then the AMT is binding (i.e., is larger than the regular tax) and Acme has an incentive to invest more in Asset A. If more than \$61.5X were invested in Asset A, then the regular tax is binding, and Acme has an incentive to invest less in Asset A. These two countervailing forces meet when Acme invests $\$ 61.5 \mathrm{X}$ in Asset $\mathrm{A}$, producing a stable outcome.
} 
incentives to fund new investment through equity or debt issuance, these might be relevant to a fuller efficiency analysis. In addition, the interplay between the regular tax and the AMT may yield incentives for mergers between marginalregular-tax and marginal-AMT firms.

4) The interplay between the two systems may increase Acme's tax planning costs. For example, the aim of equalizing regular tax and AMT liability becomes more challenging if we add to the picture realistic economic uncertainty about the company's expected revenues.

5) Having two systems instead of just one may also increase Acme's compliance costs. For example, given how carefully the AMT was designed to handle timing differences between the two systems, such as that resulting from their providing for asset depreciation at different rates, ${ }^{61}$ Acme would have to keep a host of duplicative records, and perform numerous duplicative computations, simply in applying mechanical rules that are seemingly the same in each system. ${ }^{62}$ To be sure, such costs might be lower today than they were when the AMT was enacted, given technological advances since that era.

In sum, the efficiency case for using the AMT to reduce inter-asset tax bias as between Assets A and B is uneasy at best. We don't know for sure that (or how much) it will advance that aim in the aggregate, and there clearly do appear to be offsetting efficiency costs. Indeed, use of the AMT to address the inter-asset bias seems clearly

\footnotetext{
${ }^{61}$ For a discussion of how the AMT handled timing differences, see Shaviro, supra note 45 at 101.

${ }^{62}$ See id. at 110-11 (discussing the administrative issue surrounding the obligation to maintain duplicative records).
} 
inferior to simply reducing (for taxpayers generally) the degree to which Asset B is taxfavored relative to Asset A. ${ }^{63}$ So the case for using the AMT would have to rest on other grounds. These might pertain to views about optics, political economy, or equity, such as the following:

1) Optics for its own sake: Suppose we believe, as leading AMT proponents in 1986 apparently did, ${ }^{64}$ that the AMT, by addressing public concern about rich individuals and big corporations paying no (or very little) tax, would increase perceptions of the tax system's fairness. It is conceivable, though far from certain, that this might improve compliance. ${ }^{65}$ One might also imagine its having positive (and desirable) effects on general perceptions of how well our social and political institutions are working.

2) Political economy: At least in 1986, the optics alone arguably increased the extent to which effective base-broadening was politically possible. In other words, it was plausible that the AMT could not have been traded in for additional uniform base-broadening. In addition, as I noted at the time, it was conceivable that interest groups opposed to economically desirable basebroadening would find their political efforts in this regard hampered, not just by the optical point, but also by their lack of uniform self-interest with regard to the AMT's marginal effects on them. For example, companies that expected

\footnotetext{
${ }^{63}$ See id. at 92 (discussing taxpayer responses to AMT preferred or disfavored assets and inter-asset bias).

${ }^{64}$ See id. at 106 ("The tax bill's greatest political asset was the hope that it would put an end to tax avoidance by profitable corporations and wealthy individuals-a hope that, in light of the impracticability of Treasury Istyle reform, depended in large part on the minimum tax.").

${ }^{65}$ See id. at 110-11 (discussing compliance related effects of the AMT).
} 
to be on the regular tax in any event might not wholly mind the AMT's disfavoring firms that would be subject to it on the margin. ${ }^{66}$

3) Equity: Suppose one takes a discontinuous view of the equity concerns raised by rising benefit from tax preferences. That is, suppose one believes that tax preferences become increasingly unfair as the distance rises between the taxpayer's effective rate and the full regular tax rate. (I myself have never found such a view normatively persuasive,${ }^{67}$ but tastes may differ.) Then the AMT would indeed address a (by stipulation) valid equity concern by requiring that tax-favored assets and activities be reallocated. Yet, even if one finds such a view of equity potentially persuasive in the abstract - despite its discontinuous approach to dollar-by-dollar tax reduction - one may struggle to explain: (a) whether, and if so why, it should apply to corporations, not just individuals; (b) how it is affected by implicit taxes ${ }^{68}$ such as Asset B's 20 percent lower pretax return than that available from Asset A; and (c) whether a single year, rather than a longer period, is adequate for comparing relative tax burdens as the AMT does. $^{69}$

\footnotetext{
${ }^{66}$ See id. at 108 ("For example, consider two companies in the same business . . . both of which use a particular preference but only one of which is potentially subject to the minimum tax. ... [O]nly one will oppose the minimum tax; the other company may even support it as a means of obtaining a competitive advantage.").

${ }^{67} I d$. at 99-100 ("An excessive focus on perception, unaccompanied by a sufficient real increase in fairness, begs the question of why and whether the system should be accepted by the public to begin with.").

${ }^{68}$ Charlotte Crane, Some Explicit Thinking About Implicit Taxes, 52 SMU L. Rev. 339, 345-47 (1999); see also David A. Weisbach, Implications of Implicit Taxes, 52 SMU L. REV. 373, 373 (1999) (“An implicit tax is simply the effect of taxes on the price of an asset. For example, if an asset is tax-preferred, the price will be bid up to reflect the tax preference.")

${ }^{69}$ Note that some aspects of the AMT, such as the AMT credit, achieve multi-year averaging to a degree, but not completely. I.R.C. §53(e) (2018) (permitting carryforward credits for prior year's minimum taxes paid).
} 
In the face of all these issues, it is hard to summon much confidence in favor of the proposition that enacting and retaining an AMT is likely to be good policy. Yet one cannot rule out the possibility that, at least barring the political feasibility of superior alternatives, a given tax system might be improved overall by adding or expanding an AMT, and/or worsened by subtracting or curtailing one, even taking account of politically feasible tradeins. So perhaps the best answer to the question of whether AMTs are ever desirable is that it depends. Perhaps, however, one's choices would need to be fairly bad in order for it to seem at all appealing.

B. Post-1986 Decline and (Partial) Fall of the AMT

In the years since the AMT's enactment, it has been scaled back periodically by Congress. Its list of the tax preference items that play a role in converting regular taxable income into alternative minimum taxable income (AMTI) has been trimmed multiple times. ${ }^{70}$ Its exemption amount shrank significantly in real terms, ${ }^{71}$ since it initially was not indexed to inflation. ${ }^{72}$ The 2017 tax act repealed the corporate AMT, a change that (despite the act's broader controversiality) triggered little if any gnashing of teeth. All this reflected how unfavorably it had come to be viewed by both policymakers and the general public.

Note, however, that this smoothing is imperfect: For tax years 2018-21, for example, the refundability is reduced to fifty percent of the otherwise available AMT credit. I.R.C. § 53(e)(2).

${ }^{70}$ For example, originally enacted version of Section 57(a)(3),(4) included tax preferences for incentive stock options and bank reserves for losses on bad debt, which have subsequently been removed as preferences. Compare Tax Reform Act of 1986, Pub. L. No. 99-514, § 57(a)(3),(4), 100 Stat. 2085 (1986), with I.R.C. § 57(a)(3),(4) (2018). The original preference in Section 57(a)(3) was removed in 1988. Pub. L. No. 100-647, 102 Stat. 3342 (1988). Section 57(a)(4) was removed in 1996. Pub. L. No. 104-188, 110 Stat. 1755 (1996).

${ }^{71}$ What Is the AMT, TAX POL'Y CTR. (last visited Jan. 11, 2020), https://www.taxpolicycenter.org/briefingbook/what-amt (discussing the growth of the AMT due to a failure to index the AMT exemption amount to inflation, until "[t]he American Taxpayer Relief Act of 2012 enacted a permanent AMT fix by establishing a higher AMT exemption amount, [and] index[ed] the AMT parameters for inflation").

${ }^{72}$ But note that it was twice raised nominally, and finally indexed to inflation in 2012. Id. 
The main causes of the AMT's worsening legislative and critical fortunes included the following:

1) Expanded scope, but to the "wrong people": For several decades, the individual AMT's reach and applicability expanded steadily, despite the lack of any legislation expansion. ${ }^{73}$ This change had two main causes. The first was the lack of any inflation indexing of its exemption amount, which therefore continually shrank in real terms. ${ }^{74}$ The second was the indirect impact of regular tax cuts, which increased the number of AMT taxpayers given that one pays the greater of the two. Yet the people increasingly subject to the AMT were not the stereotyped high-income tax avoiders, but rather people towards, but not at, the top, who had significant disallowed items such as state and local income tax deductions. Thus, in New York law firms, it became known as the "associates tax," reflecting that young lawyers who were associates commonly paid it, in contrast to both the more senior partners (who earned too much) and the clerical staff (who earned too little). This helped to ensure that the agitas aroused by people's having to compute the AMT would be unmitigated by any sense of its justification by the stated purposes.

2) Devolution of the AMT base: With relatively clear income tax preferences (such as accelerated depreciation) being removed from the income tax base, ${ }^{75}$ its impact

\footnotetext{
${ }^{73}$ Id. (showing in Figure 1 how "the number of taxpayers affected by the AMT continued to grow throughout the [1980s and 1990s] (figure 1) because (1) the regular income tax was indexed for inflation, but the AMT was not; and (2) Congress enacted substantial cuts to the regular income tax"). This failure to index the AMT to inflation caused the number of individuals impacted by the AMT to rise from approximately one million in 1998 to nearly five million in 2005. Id.

74 To not shrink in real terms, the $\$ 45,000$ exemption available to married couples filing jointly in 1998 would need to have risen to approximately $\$ 53,000$ by 2005 . Consumer Price Index, FED. RES. BANK OF MinNEAPOLIS (last accessed Feb. 20, 2020) (presenting the consumer price index).

75 See Additional First Year Depreciation Deduction, 84 Fed. Reg. 185, 50,108, 50,118 (Sept. 24, 2019) (discussing how Section 168(k)(2)(G)'s accelerated depreciation deduction "is allowed for both regular tax and alternative minimum tax (AMT) purposes").
} 
increasingly reflected its treatment of items that were ambiguous or controversial. In particular, AMT liability commonly turned on one's living in a high-tax state, having a lot of children who triggered personal exemptions, or having high miscellaneous itemized deductions, such as for attorneys' fees paid out of the gross returns from suing tortfeasors. ${ }^{76}$ This once again promoted an (accurate) image of the AMT as doing things quite different from those invoked in support of its enactment.

3) Changing political and policy concerns around tax avoidance: To a degree, shrinking support from the AMT may have followed from the 1986 Act's very success in reducing (for a while) stories about massive tax avoidance by high-income individuals and big corporations. ${ }^{77}$ While, by the late 1990 s, such concern began to reemerge, ${ }^{78}$ this time around it was clear that the existing AMT was not properly designed to respond to them. Aggressive tax avoidance now typically exploited structural features of the income tax that, for example, allowed for the creation of inflated basis that could be used to trigger artificial losses - with any offsetting phantom gain being assigned to tax-indifferent parties - rather

\footnotetext{
${ }^{76}$ See generally Who Pays the AMT, supra note 6 (describing the aups that increasingly are subject to the AMT, including how "[i]t was also more likely to hit taxpayers with large families, those who were married, and those who lived in high-tax states"); see also Klaassen v. Comm'r, 76 T.C.M. 20 (CCH) (1998) (holding that the AMT liability can apply without special consideration for large families). Miscellaneous itemized deductions (including attorneys' fees) are completely disallowed in computing the AMT. I.R.C. § 56(b)(1)(A)(i); see also Gregg D. Polsky, Taxing Litigation: Federal Tax Concerns of Personal Injury Plaintiffs and Their Lawyers, 22 FLA. TAX REV. 120, 137 \& n. 55 (2018) (discussing the taxation of attorneys' fees, among other miscellaneous deductions).

${ }^{77}$ This success may have been less due to the AMT itself than to other such changes as the enactment of the passive loss rules (I.R.C. § 469), the repeal of the investment tax credit, and the scaleback of accelerated depreciation.

${ }^{78}$ See e.g., Joseph Bankman, The New Market in Corporate Tax Shelters, 83 TAX Notes InT'L, June 28, 1999 at 1775, 1777-80, https://www.taxnotes.com/tax-notes-international/tax-policy-issues/new-market-uscorporate-tax-shelters/1999/06/28/7587061 (writing about a number of (then) contemporary tax shelter schemes, which did not harm the reporting of book income); David A. Weisbach, Ten Truths About Tax Shelters, 55 TAX L. REV. 215 (2002) (similarly discussing the prevalence and characteristics of tax shelter in the late 1990s).
} 
than using specified tax preferences such as those that had featured in 1980s tax shelters. ${ }^{79}$ For an AMT structure to work, one would need an expanded income measure that included items that often were not present in adjusted gross income, or even gross income.

4) Political economy playout: Things might have been different had the 1986 political economy playout remained robust. Again, in 1986, items that were sacred cows within the regular tax seemingly could nonetheless be addressed by expanding the AMT. However, this pattern did not persist, presumably reflecting the AMT's increasingly despised status. Instead, to thoughtful observers (whether or not this mattered politically), it became clear that the AMT's main influence on new enactments was to decrease public understanding of them, because its indirect impact on regular tax cuts was not widely understood. A case in point was the 2001 tax cuts proposed by President George W. Bush, the estimated revenue cost of which would have been much higher but for the increased AMT liabilities that it triggered. ${ }^{80}$ Insofar as voters, in effect, did not read the fine print, this meant that they could be led to expect larger tax cuts than they were actually getting, while the revenue estimates helpfully (for the proponents) reflected reality rather than perception. It is plausible that the upshot, increased income tax liability in subsequent years, was blamed on the AMT, not the tax cut's proponents, even though the latter knew about it in advance.

\footnotetext{
${ }^{79}$ See Bankman, supra note 78.

${ }^{80}$ See Aviva Aron-Dine \& Robert Greenstein, Ctr. Budget and Pol'y Priorities, The AMT's Growth Was Not "Unintended": How the AdMinistration and Congressional Leaders Anticipated the AMT Problem And Knowingly Made It Worse 3 (Nov. 30, 2007) ("Congressional leaders could have ... used some of the $\$ 1.35$ trillion available for the tax bill to modify the AMT so that it did not affect rapidly increasing numbers .... But then they would have had fewer dollars to enact other tax

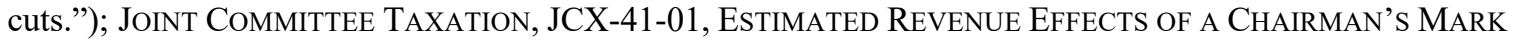
OF THE "Restoring EARNINGS TO LifT INDIVIDUALS AND EMPOWER FAMILIES ('RELIEF') ACT OF 2001" 8 (2001) (estimating the increase in the number of AMT eligible households after the 2001 tax cuts).
} 
In the aftermath of the 2017 act, public concern (at least on the left) about low taxes paid by the wealthy and highly profitable corporations has risen sharply. Yet, reflecting the history described above, this has prompted little movement to restore the AMT's 1986 role. There is still a question, however, of what lessons have been or should have been learned from the 1986 experiment, at least insofar as they might relate to current foci of concern. This should be of especial interest given that new types of minimum taxes, albeit different in many ways from the AMT, are increasingly prominent in both the Internal Revenue Code and public debate. Here, then, is a list of key takeaways from the AMT's history that may be of especial interest going forward:

1) The case for addressing "too much" tax avoidance by a given taxpayer was weakened by the AMT's methodology of addressing asset-specific tax preferences: A number of the AMT tax preferences pertained to particular assets, such as those benefiting from accelerated depreciation. In several ways, this undermined the case for using the AMT to reduce the overall use of tax preferences. For example:

a) Suppose one reason for favoring the AMT was the view that a large gap between regular taxable income and AMTI (presumed to be closer to economic income) indicated unusually aggressive tax planning or other questionable behavior. This rationale would not really apply to being in a company in a particular industry that happened to use a lot of tax-favored assets. ${ }^{81}$ Moreover,

\footnotetext{
${ }^{81}$ By contrast, the "large gap" or "aggressive taxpayer" rationale might apply to a taxpayer whose use of accelerated depreciation reflected its being a common feature of pre-1986 tax shelters. See DEP'T OF Treasury, The Problem of Corporate Tax Shelters: Discussion, Analysis and Legislative PROPOSALS 11, 134-45 (1999) (discussing many of the pre- and post-1986 corporate and individual tax shelters, which often relied on accelerating depreciation). In other respects, however, the 1986 Act had effectively curtailed such shelters, for example, by scaling back accelerated depreciation, repealing the investment tax credit that had typically played a complementary role in pre-1986 shelters, and enacting the
} 
while the application of the AMT to such companies had the potential to reduce the allocative effect of the preferences, it also might encourage inefficient ownership shifts instead.

This problem did not apply to all of the items that the AMT disfavored relative to the regular tax. For example, consider its disallowance of individuals' personal exemptions and itemized deductions for state and local income taxes paid. Here, while the disallowance could be questioned on the merits (depending on one's view as to the items' preferentiality and/or normative desirability), the response of merely reshuffling who claimed the preferences was considerably less available.

Looking forward, one lesson to keep in mind is that a minimum tax structure makes more sense, all else equal, when taxpayers cannot easily respond by reshuffling the affected assets or activities, than when they can. A second lesson is that the case for a minimum tax structure may tend to be stronger when a large gap between regular and minimum tax liability is suggestive of undesired behavior, such as aggressive tax avoidance, than when it may merely reflect, say, specializing in the use of particular types of assets.

2) The 1986-era "optics" case for using the AMT was already weak at the time, and subsequently grew weaker still: Even at the time of the 1986 Act, I questioned the contemporary view that a key AMT virtue was its increasing the tax system's perceived

\footnotetext{
passive loss rules. See David W. Brazell et al., Off. of Tax Analysis, Dep't of Treasury, A History of Federal Tax Depreciation Policy 22-25 (OTA Paper No. 64, 1989) (providing a contemporary discussion of the 1986 tax act's tightening of depreciation acceleration and the removal of the investment tax credit); Andrew A. Samwick, Tax Shelters and Passive Losses After the Tax Reform Act of 1986, in EMPIRICAL FoundaTIONS of Household TAXATiOn (Martin Feldstein \& James M. Poterba eds., 1996) (discussing the impact of passive loss rules on tax shelters).
} 
fairness. As would have been all too clear under a "just one cent" version of the AMT, it is not always a good thing to mask public awareness of what arguably are broader problems by trivially changing a given system's optics. I also questioned encouraging policymakers to turn from issues of substance to what I dubbed "perception management." 82

A lesson learned since 1986 is that rules aimed at the tax system's optics can play out unpredictably over time. For example:

a) Interest groups that in 1986 had trouble resisting base-broadening within the AMT, given its link to perceived fairness, seem to have found this much easier later on, when the public's attention had shifted to other things. Once that had happened, narrowing the AMT was far too esoteric a change to attract adverse public attention.

b) The public's lack of understanding of how the AMT affected overall tax burdens had the capacity to sway political optics in multiple ways. For example, in 2001 it may have aided enactment of the Bush tax cuts, by encouraging focus on just the regular tax effects, without regard to partially offsetting increases in AMT liability. Conversely, in 2017 it may have sharpened opposition to that year's tax act, by causing Blue Staters to overestimate the adverse impact on them of scaling back the regular tax allowability of state and local income tax deductions. ${ }^{83}$

\footnotetext{
${ }^{82}$ Shaviro, supra note 45 at $91-93$.

${ }^{83}$ I.R.C. 164(b)(6) (2018) (permitting deductions up to $\$ 10,000$ for state and local taxes when computing the regular tax obligation, not when computing the AMT obligation).
} 
c) A broader takeaway is that optical effects on perceived tax burdens may tend to be inherently unstable and unpredictable. However, making the overall tax system more complex, and even less transparent than it might otherwise be, is not in general a formula for creating better outcomes or greater adherence to the public's policy preferences (to the extent that these exist).

3) The AMT's focus on specific income tax preferences, rather than on broader tax avoidance methodologies, did not age well: The AMT's implicit diagnosis of undesired tax avoidance as reflecting the use of specific income tax preferences is understandable, in retrospect, given such items' heavy use in classic 1970s and 1980s tax shelters. ${ }^{84}$ However, it proved considerably wide of the mark once tax avoidance technologies had moved onto exploiting such structural features of federal income tax law as the realization requirement, ${ }^{85}$ and such features of the international tax regime as its enabling profitshifting and the use of tax-indifferent counterparties. ${ }^{86}$ A modern effort to use a minimum tax approach to address wholesale tax avoidance by wealthy individuals and highly profitable corporations would need to use a technology quite different from that of adding specified preferences to regular taxable income.

\footnotetext{
${ }^{84}$ See James R. Hines, Jr. \& Kyle D. Logue, Understanding the AMT, and Its Unadopted Sibling, the AMxT, 6 J. LEGAL ANALYSIS 367, 388 (2014) (discussing contemporary motivations to the implementation of the AMT); DEP'T OF TREASURY, supra note 81 at 9 \& n. 27 (1999) (citing New York State Bar Association (Tax Section), Report on Corporate Tax Shelters of New York State Bar Association Tax Section, 83 TAX NOTES 879, 884 (1999)) (describing various individual tax shelters used in the 1970s and 1980s).

${ }^{85}$ See e.g., Joseph Bankman \& Daniel Shaviro, Picketty in America: A Tale of Two Literatures, 68 TAx L. REV. 453, 504-08 \& n. 221 (2014) (discussing how wealthy individuals can use a "buy/borrow/die" scheme to avoid realizing taxable gain while still consuming the benefit of the income).

${ }^{86}$ See e.g., Clemens Fuest \& Nadine Riedel, Tax Evasion and Tax Avoidance: The Role of International Profit Shifting, in Draining Development?: Controlling Flows of Illicit Funds from Developing COUNTRIES (Peter Reuter ed., 2012).
} 


\section{A Minimum OR OTHER TAX ON CORPORATE FinANCIAL STATEMENT INCOME?}

\section{A. Background}

Critics of corporate tax avoidance frequently decry the phenomenon in which large public corporations combine paying zero in current year federal income taxes with reporting huge profits to their shareholders. In 2015, for example, seventeen major U.S. companies reported accounting profits in excess of $\$ 1$ billion, yet paid no corporate income tax ${ }^{87}$ Moreover, such disparities are neither cherry-picked nor idiosyncratic. The "booktax gap," or aggregate excess of public companies' book income over their taxable income, which first began attracting attention in the 1990s as a possible indicator of aggressive tax planning, has been large and fairly stable since at least that time. ${ }^{88}$

One possible response to the headline cases, and/or to the book-tax gap, is to make book income relevant to the overall federal taxes owed by large public companies (or perhaps more generally). This, in turn, might be motivated by concern about one or more of the following: (1) the headline stories' optical effects, (2) suspected underlying corporate tax avoidance, and (3) overall corporate tax burdens, if one believes that they are both (a) too low, and (b) better or more easily raised by focusing on book income than otherwise.

Once one has gotten this far, a question arises as to whether any tax imposed on book income should have a minimum tax structure, in the sense of being conditioned on

\footnotetext{
87 See Matthew Gardner et Al., The 35 Percent Corporate Tax Myth: Corporate Tax Avoidance BY FORTUNE 500 COMPANIES, 2008 TO 20154 (2017) (listing eighteen examples of major firms that paid no corporate taxes between 2008 and 2015, with only Priceline.com earning less than \$1 billion in profits over those years).

${ }^{88}$ See Danielle H. Green \& George A. Plesko, The Relation Between Book and Taxable Income Since the Introduction of the Schedule M-3, 69 NAT'L TAX J. 763 (2016). Green and Plesko find that the book-tax gap has generally been growing in absolute terms, but remaining stable as a percentage of book income. Id. at 778. It temporarily dipped and indeed turned negative, however, amid in the recessionary years of 2001 and 2008. Id. at 773 fig. 5.
} 
whether a given company's regular tax liability is otherwise "too low." To such effect, the 1986 corporate AMT briefly included an item that was known colloquially as the bookincome preference. Under this provision, just for tax years beginning in 1987 through 1989, corporations, after computing their AMTI in all other respects, would be required to increase it by half of the amount, if any, by which their "adjusted net book income" (generally, their financial statement income, with specified adjustments) exceeded such AMTI. ${ }^{89}$ For tax years starting in 1990 or thereafter, however, it was replaced by an adjustment to AMTI that relied purely on tax measures of income. ${ }^{90}$

The pre-selected 1990 change proved not, however, to be the end of the story, with respect either to taxing book income or using a minimum tax to do so. In the Democratic primary run-up to the 2020 presidential campaign, Vice President Joe Biden proposed taxing companies' book income at a fifteen percent rate (subject to a $\$ 100$ million exemption amount) to the extent that such amount exceeded their regular tax liabilities. ${ }^{91}$ Senator Elizabeth Warren proposed a seven percent levy on (roughly) the same book

\footnotetext{
${ }^{89}$ See Shaviro, supra note 31, at 100; I.R.S., StATISTICS OF InCOME Bulletin 72 (Summer, 1993) (“In addition, for Tax Years 1987-1989, there was a book income adjustment in deriving the income base of the AMT."); 26 C.F.R. § 1.56-1(a)(1) (2013) ("For taxable years beginning in 1987, 1988, and 1989, the alternative minimum taxable in-come of any taxpayer is increased by the book income adjustment described in this paragraph (a)(1).").

${ }^{90}$ See, e.g., Linda M. Beale, Book-Tax Conformity and the Corporate Tax Shelter Debate: Assessing the Proposed Section 475 Mark-to-Market Safe Harbor, 24 VA. TAX L. REV. 301, 351-52 \& n. 133 (2004).

${ }^{91}$ See, Jim Tankersley, N.Y. Times, Biden Proposes Smaller Tax Increases Than Rivals Do (Dec. 4, 2019) (describing Biden's proposals for corporate tax reform, which "include a type of alternative minimum tax of 15 percent on companies' total revenues worldwide, with credit given for taxes paid in foreign countries"); Jennifer Epstein, Bloomberg, Biden to Target Tax-Avoiding Companies Like Amazon with Minimum Federal Levy (Dec. 4, 2019 4:00 A.M.) ("Biden would introduce a 15\% minimum tax on book income aimed at companies that reported net income of more than $\$ 100$ million in the U.S. but paid zero or negative federal income taxes.").
} 
income that would be payable in any event. ${ }^{92}$ Biden, therefore, was proposing a new corporate alternative minimum tax, albeit one based purely on book income (as adjusted) rather than on a broader range of items identified as preferential. Warren, by contrast, was proposing a new stand-alone tax instrument.

The question of interest here is whether, if Congress once again causes book income to have direct federal tax consequences, ${ }^{93}$ this should be done through a minimum tax that conditions the amount otherwise due on its exceeding regular income tax liability. I take it as given, for this purpose, that book income is indeed being given tax consequences, one way or the other. ${ }^{94}$ As it happens, however, the broader underlying question about taxing book income is hotly contested. Financial accounting scholars tend, verging on unanimously and often vehemently, to oppose taxing book income through any mechanism. ${ }^{95}$ By contrast, some economists and legal scholars support the idea, at least

\footnotetext{
${ }^{92}$ Warren, supra note 9 (proposing a supplemental seven percent tax on corporate book profits in excess of one-hundred million dollars, rather than a minimum tax).

${ }^{93}$ Under existing law, book income can affect regular tax liability in more limited ways. See I.R.C. § 472(c) (limiting taxpayers' ability to use last-in-first-out (LIFO) inventory accounting for tax purposes if they are not using it for other purposes, such as in their financial accounting). For better or worse, however, this "LIFO conformity rule" has grown quite ineffective over time. See Edward D. Kleinbard et al., Is It Time to Liquidate LIFO?, 113 TAX NOTES 237 (2006).

${ }^{94}$ If this were being done, a further question would be whether to apply the instrument to companies other than those that file financial accounting statements with the SEC by reason of being publicly traded. The 1986 book-income preference applied more broadly, using as needed financial statements that had been supplied outside the regime for public companies to such counterparties as prospective lenders and investors. See I.R.C. § 56(f)(3)(A) (1986) (defining the applicable financial statement to be SEC filings where appropriate, but also permitting the use of any financial statement used to obtain credit or provided to shareholders).

${ }^{95}$ See Jeff Hoopes, UNC TAX CTR.: Tax Blog, What Do Academic Accountants Think of Senator Warren's "Real Corporate Profits Tax"? (Oct. 3, 2019), https://tax.unc.edu/index.php/news-media/what-doacademic-accountants-think-of-senator-warrens-real-corporate-profits-tax ("The short version of the commentary is that we don't like the proposal.").
} 
conditionally. ${ }^{96}$ While this debate is not directly relevant here, ${ }^{97}$ it helps to illuminate the structural choice, in part because the empirical claims made on each side of the debate would affect the playout of each approach. Also relevant, however, are the particular reasons advanced for (and against) taxing book income, along with the broader design issues posed by seeking to make tax use of a financial accounting measure.

B. Significance of the Main Rationales for Taxing Book Income

\section{Optical Effects of Not Taxing Companies with Large Reported Profits}

Just as in 1986, when Congress used the AMT to head off newspaper stories about high-profile tax avoidance, so today a minimum tax offers an obvious mode of response if the concern goes primarily to such optics. One should keep in mind, however, that this comes at the price of various side effects that the AMT helped show. These include, for example, giving companies diverse incentives that may differentially distort their choices, depending on whether or not they are taxable on book income at the margin; and inducing wasteful planning to equalize regular tax and minimum tax liability.

\section{Aim of Raising Overall Corporate Tax Burdens}

\footnotetext{
${ }^{96}$ See e.g., Mihir A. Desai \& Dhammika Dharmapala, Earnings Management, Corporate Tax Shelters, and Book-Tax Alignment, 62 NAT'L TAX J. 169, 169 (2009) (reviewing extant evidence and Economics models and concluding "that shareholders and policymakers should question the rationale for distinct financial reports and that greater book-tax alignment may have mutually beneficial effects for investors and tax authorities"); Daniel Shaviro, The Optimal Relationship Between Taxable Income and Financial Accounting Income: Analysis and a Proposal, 97 GEO. L.J. 423, 429 (2008) (proposing averaging tentative taxable income with book income in order to obtain the final taxable corporate income amount, akin to the old corporate AMT). But see, Michelle Hanlon et al., Evidence for the Possible Information Loss of Conforming Book Income and Taxable Income, 48 J.L. \& ECON. 407, 407 (2005) (measuring how conforming book and tax income measurements produces "a loss in information content to investors").

${ }^{97}$ It is worth noting, however, that while financial accounting scholars' expertise supports taking their concerns very seriously, they may be subject to "NIMBY" ("not in my backyard") thinking, in the sense of particularly objecting to adverse effects on financial reporting, as distinct from other inputs to an overall social welfare assessment. Tax experts may similarly be inclined to respond disproportionately to tax distortions, such as those that may result from granting particular tax preferences, relative to other inputs to an overall assessment.
} 
An alternative ground for favoring a tax on book income is simply to raise overall corporate tax burdens. Of course, this could also be done through more conventional means, such as raising corporate income tax rates or broadening the base through purely tax-based changes. However, the use of book income might be thought to have political economy advantages. Or alternatively, its use might be thought beneficially to diversify the types of distortions that are being imposed. ${ }^{98}$ If this is the motivation, only political economy concerns about the effects of tax avoidance optics would appear potentially to support using a minimum tax approach, rather than more straightforwardly taxing book income.

\section{Suspected Underlying Corporate Tax Avoidance}

Suppose one believes that a given company's book-tax gap is itself informative regarding true economic income and the company's likely level of socially undesirable tax sheltering behavior. Then taxing financial accounting income, wholly without regard to its relationship to regular taxable income, would constitute failing to take use of this information. A minimum tax approach, by contrast, does make use of it.

This is not to say, however, that such use needs to take a minimum tax form. Suppose instead that, after taxable income had been preliminarily computed without regard to book income, one added a percentage of the resulting book-tax gap to the final measure of taxable income. ${ }^{99}$ This, unlike a standard minimum tax structure, would cause the gap

\footnotetext{
${ }^{98}$ See, e.g., Gamage, supra note 34 at 4 (arguing how a diversity of tax distortions may be more valuable than a single-minded focus on minimizing aggregate distortion).

${ }^{99}$ This would resemble how AMTI was computed under the book-income preference that applied from 1987 through 1989. See Dan Dhaliwal \& Shiing-wu Wang, The Effect of Book Income Adjustment in the 1986 Alternative Minimum Tax on Corporate Financial Reporting, 15 J. ACCT. \& ECON. 7, 9 (1992) (describing the mechanics through which AMTI was calculated with the book-income preference).
} 
to increase tax liability even when it was relatively small. ${ }^{100}$ This would permit one to avoid so crisply dividing the universe of corporate taxpayers into regular tax and AMT clienteles. $^{101}$

Once one is looking directly at the book-tax gap, rather than at two distinct but interdependent measures of tax liability, a natural next step might be to purge it of inputs that one concluded were not indicative of the tax avoidance behavior that was being targeted. For example, one could conform the two measures' treatment of asset-specific preferences (such as depreciation) for purposes of the inclusion. ${ }^{102}$ One could also try to identify and adjust for other differences between the book and tax treatment of particular items that one concluded were not indicative of the tax avoidance behavior that one was seeking to address. ${ }^{103}$

C. Empirical Issues Raised in the Debate Over Taxing (or Not) Book Income

\section{Effects on Managerial Agency Costs and the Quality of Information Supplied to} Investors

\footnotetext{
${ }^{100}$ For example, say the regular tax rate is a flat twenty percent. Including half of the book-tax gap in final taxable income would lead to the same overall tax liability as having a flat ten percent book income AMT, in cases where one's book income was at least double one's pre-adjustment taxable income and one therefore was on the AMT at the margin. However, the two approaches would differ where book income was less than twice preliminary taxable income. For example, say preliminary taxable income is $\$ 1$ billion and book income is $\$ 1.5$ billion. Then the taxpayer would owe no additional tax under the book income AMT, but would owe an additional $\$ 50$ million of tax (i.e., twenty percent of $\$ 250$ million) under the addition-toincome approach.

${ }^{101}$ But note clienteles could still emerge if, for example, taxable income was not commensurately reduced in the case of a negative book-tax gap (i.e., where preliminary taxable income is in excess of book income).

102 See supra notes 58-63 and accompanying text, however, for a discussion against asset-specific preferences in with an AMT.

${ }^{103}$ Such adjustment could also be done under an AMT structure if one bases the comparison of the regular tax to the minimum tax on adjusted computations of liability under one or both systems, but this may be more complicated and/or less intuitively straightforward.
} 
It is widely recognized that the managers of publicly traded corporations have an incentive to reduce taxable income. They also have an incentive to smooth financial accounting income between periods, as well as to increase it in near-term periods if agency costs give them short time horizons or unduly steep discount rates. ${ }^{104}$ Accordingly, giving adverse tax consequences to book-tax gaps might be viewed as having "the desirable feature of creating ... tension between the managers' twin aims, reducing the incentive to play games and the scope of what they could accomplish.""105

This argument suggests that penalizing book-tax gaps (whether or not through a minimum tax) has the potential to improve the information that is available to investors. Under such a view, neither a minimum tax approach to taxing book income like that of Vice President Biden, nor a stand-alone tax approach like that of Senator Warren, takes full advantage of this potential. The latter fails to address book-tax gaps as such, by relying purely on the amount of book income. The former focuses on the gap to a degree, but its clientele effect seems anomalous. Under Vice President Biden's proposal, firms that are under the regular tax at the margin would have no immediate reason to limit the extent to which they seek to increase book income independently of taxable income.

There is reason, however, to question whether penalizing book-tax gaps would actually improve the information available to investors. Empirical research regarding the effects of the 1986 act's book-income preference suggests that it not only (as one would expect) influenced reported profits, such as by causing them to be shifted from inside to

\footnotetext{
${ }^{104}$ See, e.g., Shaviro, supra note 96 at 445-49.

${ }^{105} \mathrm{Id}$. at 484 . Alternatively, one could respond to managers' incentives to overstate financial accounting income by taxing it directly, without regard to how it compares to taxable income. Given, however, that actual increases in profits are in the shareholders' interest, there is a reasonable case for focusing the pushback on book-tax gaps in particular.
} 
outside the 1987 to 1989 window, ${ }^{106}$ but also reduced financial statements' overall informativeness to investors. ${ }^{107}$

While this research leans against doing anything to penalize book-tax gaps, it lacks clear structural implications regarding how best to do so, if one is nonetheless proceeding. The clientele effects of employing a minimum tax structure might now to a degree be welcomed, since they would at least insulate firms that face the regular tax at the margin from issuing less informative financial statements. This, however, would come at the cost of the clientele effects' undesirability in other respects.

\section{Effects on Political Choice}

A key reason for concern about allowing financial accounting income to affect tax liability goes to how this might affect the applicable rules for measuring it. In the United States, the Financial Accounting Standards Board (FASB) sets these rules for public companies. ${ }^{108}$ FASB is a "quasi-independent, though accounting-industry staffed, government agency under the purview of the Securities and Exchange Commission (SEC)." 109 While FASB is not exempt from undesirable political influence-interest groups regularly try to lobby it, and it has faced accusations of "unduly serv[ing] accountants' interests relative to those of investors" ${ }^{110}$ - there is nonetheless historical

\footnotetext{
${ }^{106}$ See, e.g., Charles E. Boynton et al., Earnings Management and the Corporate Alternative Minimum Tax, 30 J. ACCT. ReSEARCH 131 (1992); Dhaliwal \& Wang, supra note 99; Jeffrey D. Gramlich, The Effect of the Alternative Minimum Tax Book Income Adjustment on Accrual Decisions, 13 J. AM. TAX'N Ass'N 36 (2001).

${ }^{107}$ See Hanlon et al., supra note 96; Michelle Hanlon et al., An Unintended Consequence of Book-Tax Conformity: A Loss of Earnings Informativeness, 46 J. ACCT. \& ECON. 294 (2008).

108 About the FASB, Fin. ACCT. Standards BoARD (last accessed Feb. 23, 2020), https://www.fasb.org/facts/index.shtml.

${ }^{109}$ Shaviro, supra note 96 at 438.

${ }^{110}$ See id. at 470.
} 
evidence suggesting that greater direct Congressional influence would make things worse. ${ }^{111}$ Causing financial accounting income to have direct tax implications might increase Congress's inclination to meddle more than it generally has to date, ${ }^{112}$ possibly leading it to "worsen financial accounting income more than improve taxable income."113

While these concerns weigh against giving financial accounting income any direct tax consequences, their implications for the structural choices of central interest here are less clear. The question of how assiduously Congress would work to worsen the financial accounting rules, under different tax models, depends on the inherently unpredictable political economy playout over time.

D. Further Design Issues Raised by Taxing Book Income

\section{International Issues}

One key difference between MNCs' U.S. taxable income and their financial accounting income is that the former excludes much of their FSI, while the latter is a worldwide income measure. Thus, imposing tax on book profits results in worldwide taxation of the companies subject to the tax - a group presumably limited to those that are U.S. residents ${ }^{114}$ — unless some other feature of the tax instrument prevents this result. The lack of a source concept would also impede taxing foreign companies on a financial

\footnotetext{
111 See id. at 471.

112 While Congress might instead confine its meddling to the tax implications of financial accounting income or book-tax differences, one not could be certain that it would so limit its interventions.

113 Shaviro, supra note 96 at 484.

114 This restriction appears to be a feature of both Vice President Biden and Senator Warren's proposals. See Reklaitis, supra note 9; Warren, supra note 9.
} 
accounting measure of their U.S. source income, even though such income generally is subject to the U.S. corporate income tax.

Might source concepts be used in a tax on financial accounting income? This is not necessarily impossible, given the rise of country-by-country reporting (CBCR) around the world. ${ }^{115}$ However, CBCR remains a work in progress. Moreover, some argue that, even if it is disseminated confidentially to inform governments, any broader use of it should be resisted. ${ }^{116}$ Absent the use of a source concept, a tax on financial accounting income presumably would only raise outbound issues for U.S. companies, as distinct from inbound issues for foreign companies. ${ }^{117}$

As a purely residence-based tax, the Warren stand-alone instrument amounts to a seven percent levy on U.S. companies' worldwide income, including their FSI. The MRR for foreign taxes paid would apparently be zero. ${ }^{118}$ The Biden minimum tax instrument would likewise be imposed on worldwide income. However, given its apparent allowance

\footnotetext{
${ }^{115}$ See OECD, GUIDANCE ON THE IMPLEMENTATION OF COUNTRY-By-COUNTRY REPORTING: BEPS ACTION 13 (2019), https://www.oecd.org/ctp/guidance-on-the-implementation-of-country-by-country-reportingbeps-action-13.pdf (discussing and providing the guidance on continued implementation of country-bycountry reporting).

${ }^{116}$ See, e.g., Michelle Hanlon, Country-by-Country Reporting and the International Allocation of Taxing Rights, 72 Bull. INT'L TAX 4/5 (2018).

${ }^{117}$ Foreign companies generally must file financial statements with the SEC if they are listed on U.S. stock exchanges or publicly offer their securities for sale in the United States. See generally, Financial Reporting Manual: Topic 6-Foreign Private Issuers \& Foreign Businesses, SeC. \& EXChange Commission (last updated Sept. 10, 2010), https://www.sec.gov/corpfin/cf-manual/topic-6 (describing the reporting obligations and procedures for foreign companies).

${ }^{118}$ See Kyle Pomerleau, An Analysis of Senator Warren's 'Real Corporate Profits Tax,' TAX Found. (Apr. 18,2019 ) (noting that under the author's modeling assumptions, there would be no deductions or credits for taxes paid, and no foreign tax credits).
} 
of foreign tax credits, it would resemble the global minimum taxes that I discuss infra in Section V. ${ }^{119}$

How should one think about this choice from a structural standpoint? There is no clear or consensus answer regarding the general desirability of taxing resident companies' FSI. ${ }^{120}$ Insofar as one wants to do this, however, a minimum tax has the usual defect of affecting only companies that have "too much" FSI relative to their U.S. source income, thereby creating clienteles and inducing activity and asset reallocation between firms that face different marginal incentives. ${ }^{121}$

\section{Annual Accounting and the Effects of Timing Differences Between the Systems}

In taxing corporate income, it has long been recognized that separate annual accounting can have distortionary effects. ${ }^{122}$ For example, even in an otherwise flat rate system, if it treats losses as nonrefundable and limits loss carryovers, investments that

\footnotetext{
${ }^{119}$ Note that the AMT allowed foreign tax credits, but that at least initially they could only offset $90 \%$ of the tax otherwise due. I.R.C. § 59(a)(2) (2000) (limiting the alternative minimum foreign tax credit to $90 \%$ of the pre-credit liability). Also, the credits were limited to offsetting the U.S. AMT on FSI, whereas the Biden proposal could not so limit them unless it uses some sort of a source concept with respect to the FSI component of financial accounting income.

${ }^{120}$ See, e.g., Daniel Shaviro, Digital Services Taxes and the Broader Shift from Determining the Source of Income to Taxing Location-Specific Rents 10-13 (N.Y.U. L. \& Econ. Research Paper No. 19-36, 2019), https://papers.ssrn.com/sol3/papers.cfm?abstract_id=3448070.

${ }^{121}$ It is true, however, that one also can have "too much" FSI by reason of engaging in extra profit-shifting, as distinct from having a greater ratio of foreign to domestic activity. Thus, suppose two U.S. MNCs had exactly the same "true" split between DSI and FSI, but that one engaged in greater profit-shifting than the other. Once that MNC faced the minimum tax on the margin, its profit-shifting would indeed be tax-penalized by the provision (causing it to pay more U.S. tax than its peer company), just as would happen in the purely domestic case where it created tax shelters that reduced taxable but not financial accounting income.

${ }^{122}$ See, e.g., Scott A. Richardson et al., The Implications of Accounting Distortions and Growth for Accruals and Profitability, 81 ACCT. REv. 713 (2006) (discussing and empirically estimating impacts that annual accounting has on firm behavior and profitability).
} 
would yield volatile earnings streams (or start-up losses) are disfavored relative to those with more level annual earning patterns.

These familiar problems can take on new dimensions when one adds a tax on financial accounting income to the picture. For a separate flat rate system like that proposed by Senator Warren, the problem is limited to the treatment of losses, plus the underutilization of annual exemption amounts in less profitable years. If one instead imposes tax on the book-tax gap, the issue shifts to one of whether one offers symmetric (taxable income-reducing) treatment to tax-book gaps, which arise when taxable income exceeds book income.

Under a minimum tax like that proposed by Vice President Biden, issues of ebb and flow between the two interacting systems create further annual accounting problems. Suppose, for example, that a large economic loss is deducted in Year 1 for book purposes, placing one under the regular tax, and in Year 2 for tax purposes, placing one on the minimum tax. Then, if both systems simply apply annually, one may end up paying regular tax in the year when it reduces book income, and the book income tax in the year when it reduces regular taxable income. This could be viewed as amounting to effective disallowance of the loss deduction in both (and all) years.

The 1986 AMT addressed this problem by offering AMT credits, which could be used to reduce regular tax liability when timing differences between the systems had generated prior year AMT liability. ${ }^{123}$ At present, the Biden plan appears to be less far-

\footnotetext{
${ }^{123}$ I.R.C. $\S 53$ (permitting a credit against future regular tax liability based on amounts paid under the AMT relating to deferral items).
} 
reaching, providing only for loss carryovers of some kind. ${ }^{124}$ While this could in principle be addressed by expanding the credit mechanism to resemble that under the AMT, it is unclear whether this would happen upon enactment.

In sum, the use of a minimum tax structure potentially worsens annual accounting problems, by raising issues of the two systems' interaction, rather than merely of how each functions as a stand-alone matter. Viewed optimistically, however, it might also conceivably raise the likelihood that such annual accounting problems as there were would be seriously addressed.

E. Summing Up, and Broader Takeaways

The experiment of taxing book income has not yet been tried, apart from the limited 1987-1989 first run. Yet, if one assumes (at least for argument's sake) that something will be done to tax book income, a survey of the issues posed suggests the following takeaways:

1) Book income presents a stronger case than 1986-style AMTI for interacting its taxation with that of regular taxable income (as determined without regard to it). Specifically, if the book-tax gap offers information regarding items of interest that cannot be observed directly—-such as true economic income, or the likely intensity of tax avoidance behavior - then causing its taxation to depend on the joint observation may help to advance underlying goals. However, this need not take the form of using a minimum tax structure, and can instead involve basing liability directly on the book-tax gap.

2) The key advantage of focusing on the book-tax gap without following a full minimum tax structure is that it might reduce the creation of clientele effects of

\footnotetext{
124 See Epstein, supra note 91 (describing Vice President Biden's tax proposal).
} 
dividing companies into subclasses that face distinct marginal incentives. Taxdriven clientele effects may distort ownership patterns, while also inducing socially wasteful managerial effort to manage the relationship between one's liability under the two interacting systems.

3) The book-tax gap might itself be adjusted, for purposes of the tax instrument. For example, one might want to purge it of items that are especially subject to the objection that their generating additional tax liability would tend merely to reallocate activity between companies. Asset-specific income tax preferences raise this concern, and so does book income's inclusion of any FSI that escapes regular tax inclusion. However, adjusting the book income measure to focus more on DSI is difficult unless one assumes that CBCR can fruitfully be employed to this end. 


\section{THE BEAT}

A. Technical Versus Purposive Minimum Taxes

There is currently no clearer case than the U.S. base erosion and anti-avoidance tax (the BEAT) of a tax instrument that pits the technical definition of a minimum tax against a purposive one. As noted earlier, the BEAT is a classic minimum tax technically, in the sense that it (1) expands the tax base by requiring that certain items be added back to regular taxable income, (2) imposes tax on that base at a rate below the regular tax rate, and (3) makes the resulting liability payable only to the extent that it exceeds regular tax liability. ${ }^{125}$ Yet, even if one believes that its adoption is good policy, this may stand on grounds distinct from viewing the expanded BEAT base as a good approximation of economic income.

The BEAT generally denies deductions for "base erosion tax benefits"- that is, payments made by the taxpayer to foreign affiliates — thereby creating a larger measure known as "modified taxable income."126 This disallowance, for purposes of the alternative measure, responds to two grounds for unease about such payments' regular tax deductibility. The first is that they may reflect aggressive transfer pricing, designed to shift reported tax profits from the United States to lower-tax jurisdictions. ${ }^{127}$ The second is that, even if the transfer prices used are reasonable, MNCs may concentrate deductible intra-

\footnotetext{
125 See Daniel N. Shaviro, The New Non-Territorial U.S. International Tax System, Part 2, TAx NotES, July 9, 2018 at 171, 172 .

${ }^{126}$ I.R.C. $§ 59 A(b),(c)$.

127 See What Is the TCJA Base Erosion and Anti-Abuse Tax and How Does It Work?, TAX PoL'Y CTR. (last accessed Feb. 23, 2020), https:/www.taxpolicycenter.org/briefing-book/what-tcja-base-erosion-and-antiabuse-tax-and-how-does-it-work (discussing how abusive transfer pricing, inter alia, motivated the BEAT).
} 
affiliate outflows, such as for royalties or interest expense, in high-tax jurisdictions, thereby shifting net income to affiliates in low-tax jurisdictions. ${ }^{128}$

Even if all this is going on, however, modified taxable income exceeds an accurate economic measure of DSI, at least with respect to the items that it disallows, unless the “correct" transfer payment was zero. ${ }^{129}$ It thereby makes the tax base arithmetically larger, as distinct from "broader" as I have defined it, in the same sense that one might say this about gross income.

This is not to deny the possibility that, in a given instance, modified taxable income under the BEAT may come closer than the regular tax to measuring economic income accurately. Suppose, for example, that Acme Products deducts $\$ 100$ million for payments to foreign affiliates, and that, using correct transfer prices, this amount would have been only $\$ 30$ million. Then, if both systems otherwise measure economic accurately, modified taxable income will come $\$ 40$ million closer than regular taxable income to having a correct bottom-line result overall. ${ }^{130}$

Even in this scenario, however, the optics would be different, given the overt erroneousness of the BEAT's approach if correct transfer prices are not generally zero. The BEAT's low rate - whether or not a minimum tax structure — plays an important role in

${ }^{128} I d$.

${ }^{129}$ Even where the issue is concentrating deductible intragroup payments in high-tax affiliates, rather than overstating transfer prices, simply disallowing the deductions may overreach. Suppose, for example, that a loan by a low-tax to high-tax affiliate generates gross income in the latter via the use of the funds. Then simply disallowing interest expense on the loan might result in over-attributing the group's net income to the high-tax jurisdiction.

${ }^{130}$ Alternatively, suppose that the correct transfer price for Acme's deductible payments to foreign affiliates is $\$ 70$ million, rather than $\$ 30$ million, but that, in other respects, both the regular tax and the BEAT undermeasure Acme's economic income by $\$ 30$ million. Then the BEAT fortuitously gets Acme's economic income exactly right, whereas regular taxable income would understate it by $\$ 60$ million. 
rationalizing its apparent overstatement of DSI. However, the fact that the BEAT is a minimum tax technically, but perhaps not purposively, poses the question of what impact the technical and purposive definitions should have on how we understand and evaluate it. B. Relevance of the BEAT's Being Technically a Minimum Tax

The prior discussion here has emphasized two main reasons why the use of a technical minimum tax structure matters. The first is that it creates incentives for taxpayers to manage carefully the relationship between their regular taxable income and that arising under the alternative measure. Recall, for example, the hypothetical in which Acme would maximize its after-tax profitability by investing $\$ 61.5 \mathrm{X}$ in Asset $\mathrm{A}$ and $\$ 38.5 \mathrm{X}$ in Asset B. The second is that, taking as given taxpayers' status as facing either the regular tax or the alternative instrument at the margin, it creates distinct clienteles that will have reason to make different economic decisions for tax reasons. Each of these can lead to inefficiency, and each arises here.

\section{Incentive to Manage the Relationship Between Regular Tax and BEAT Liability}

In the earlier Acme hypothetical, the taxpayer would have reason to spend (and, from a social standpoint, waste) resources on tax planning designed to optimize the after-tax yield from its mix between holdings of Asset A and Asset B. At least, however, its deciding to hold some of Asset A (with its ten percent pre-tax return), rather than just Asset B (with its eight percent pre-tax return), may indicate some element of societal efficiency gain if both: (a) pre-tax returns accurately measure relative social value, and (b) asset reallocation between taxpayers does not eliminate the overall shift from B towards A.

Under the BEAT, the incentives story is considerably more complicated. Suppose we start from the premise that, under the regular tax, firms have an incentive to overuse 
deductible payments to foreign affiliates, from the standpoint of maximizing their expected pre-tax profitability, given the after-tax benefit to be gained by shifting net income out of the United States. ${ }^{131} \mathrm{~A}$ firm that wants to avoid the BEAT can respond to the prospect of deduction disallowance in a number of different ways, including the following:

1) It may shift to procuring goods and services domestically or from third parties, rather than from foreign affiliates.

2) It may reorganize its internal production chains so as to reduce deducible payments to foreign affiliates. An example would be to buy from such affiliates inventory that derives its value from underlying intellectual property (IP), in lieu of paying deductible royalties for the IP. ${ }^{132}$ This would avoid creating BEAT inclusions, since the BEAT does not reach payments (such as for inventory) that, rather than being deductible, are added to the cost of goods sold. ${ }^{133}$ The firm may also respond to the BEAT by otherwise reorganizing its global network, such as by reducing production in the United States that makes use of affiliate inputs from abroad.

3) It may focus on other margins that affect the BEAT's applicability. For example, the BEAT generally does not apply if, for the taxable year, less than three percent

${ }^{131}$ See Grubert \& Altshuler, supra note 10 at 675-76 (discussing various tax planning possibilities, including shifting income out of the United States). For present purposes, we need not resolve the question of whether efficiency, for this purpose, is measured from a U.S. national welfare standpoint or from of global welfare standpoint. Axel Gosseries, International Justice, in The Oxford Handbook of Practical Ethics 459 (Hugh LaFollette ed., 2005).

${ }^{132}$ See Shaviro, supra 125 at 177.

${ }^{133}$ See id. at 173. 
of one's total deductions were base erosion tax benefits. ${ }^{134}$ Taxpayers can therefore manipulate their overall deductions and/or their overall payments to foreign affiliates, with an eye to staying just off the BEAT, rather than subject to it.

At each of these margins, the BEAT may induce taxpayers to make changes that reduce expected pre-tax profitability. It may also, however, offset preexisting distortions that likewise would have reduced pre-tax profitability. Suppose, for example, that it deters a given MNC from engaging in tax-driven structuring that had served, at some pre-tax cost, to increase the scope of feasible transfer pricing manipulations. The BEAT's efficiency effects on firms' decisions are therefore likely to be mixed.

More pertinent here is the question of why a minimum tax structure should be used in determining when the tax benefit otherwise realized from deductible payments to foreign affiliates should be scaled back. Even granting that one cannot readily ascertain what level of deductibility would be "just right," it is hard to see why the permitted marginal effects should depend on the relationship between regular tax liability and stand-alone BEAT liability. ${ }^{135}$ For example, it is unclear why the ratio between base erosion tax preferences and other items on the tax return should be thought to shed any light on the relationship between regular taxable income and economic income.

\footnotetext{
${ }^{134}$ See id. I have argued elsewhere that this rule serves no discernible good purpose, and creates bizarre "notches" in tax liability, since crossing the threshold, due even to a one-dollar change in one's base erosion tax benefits or other deductions, may lead discontinuously to a vastly larger change in one's net U.S. tax liability. E.g., id. at 176.

135 This may induce firms to do complicated scenario planning, for example, if sales levels that are not fully predictable in advance will affect the amount of base erosion tax benefits and overall deduction items incurred in a particular year.
} 
Use of the BEAT is arithmetically equivalent to otherwise allowing deductions for base erosion tax benefits, but then subjecting them to an excise tax. ${ }^{136}$ The rate of excise tax is zero percent until one initially faces the BEAT at the margin, and twenty-one percent (i.e., equal to the regular tax rate) thereafter. ${ }^{137}$ Or, to put in terms of the MRR that applies to base erosion tax benefits, net of the effects of regular tax liability, it is initially twentyone percent, but then it shifts to zero percent at the moment when one first faces BEAT liability at the margin. It is not clear why this would be an optimal structure, even disregarding the clientele effects that I discuss next. ${ }^{138}$

\section{Division of firms into regular tax-minimizing and BEAT-minimizing clienteles}

At the firm level, the BEAT's use of a minimum structure gives rise to sharply discontinuous MRRs. At the industry level, insofar as firms will regularly either be on the BEAT or else not, it gives rise to two sharply distinct clienteles. Here, just as in other contexts discussed above, this may differentially affect firms' asset choices, ability to

\footnotetext{
${ }^{136}$ See Shaviro, supra 125 at $175-176$.

${ }^{137}$ Suppose, for example, that a given taxpayer has $\$ 21 \mathrm{X}$ of regular taxable income and zero base erosion tax benefits (hence, $\$ 21 \mathrm{X}$ of BEAT income), but that it can then simply add such benefits a dollar at a time, thereby reducing its regular taxable income but not its BEAT income. In this scenario, the first \$11X of base erosion tax benefits - reducing regular taxable income to $\$ 10 \mathrm{X}$, while BEAT income remains $\$ 21 \mathrm{X}$ - lowers the taxpayer overall liability from $\$ 4.41 \mathrm{X}$ to $\$ 2.1 \mathrm{X}$. Hence, the benefits' regular tax deductibility (at a 21 percent MRR) is not offset by any positive excise tax. Beyond that point, however, base erosion tax benefits generate no reduction in overall tax liability, despite their continued regular tax deductibility, since the taxpayer's BEAT liability, now the greater of the two, remains $\$ 2.1 \mathrm{X}$. Hence, in this range it is as if the benefit of regular tax deductibility was being offset by a 21 percent excise tax.

${ }^{138}$ Cf. Alan S. Blinder and Harvey S. Rosen, Notches, 75 Am. Econ. Rev. 736 (1985); Joel S. Slemrod, Buenas Notches: Lines and Notches in Tax System Design, eJournal of Tax Research, 2013, 11 (3), 259.
} 
attract capital, and decisions to seek or avoid common ownership (among other variables). ${ }^{139}$

C. Relevance of the BEAT's Not Being Purposively a Minimum Tax.

As noted above, the BEAT arguably is not a minimum tax in the purposive sense, even though it is one technically, given the well-recognized normative shortcomings of its larger (but not necessarily broader in the normative sense) tax base. This distinguishes the BEAT from both the AMT and a book income minimum tax, each of which is more easily rationalized as offering an appealing (even if imperfect) measure of economic income.

This distinction is important to how the BEAT might best be modified, or its aims advanced by other means. In particular:

1) When one views a given minimum tax base as normative, adopting it as a wholesale replacement for the regular tax may become appealing. Thus, around the time of the 1986 Act, there were calls for making the AMT the operative tax base, and wholly eliminating the regular tax after a few transitional years. ${ }^{140}$ Likewise, there have more recently been calls for wholly replacing statutory taxable income with financial accounting income as the operative tax measure. ${ }^{141}$ With respect to the BEAT, any such advocacy would require that one be comfortable with its employing elements of gross income taxation, as

\footnotetext{
${ }^{139}$ Clienteles would arise to a degree under any non-flat excise tax, or non-uniform set of MRRs. However, the sharp break between zero percent and twenty-one percent MRRs (or excise tax rates) gives rise to a distinction that is especially sharp.

${ }^{140}$ See, e.g., Graetz, supra note 24; Michael J. Graetz \& Emil M. Sunley, Minimum Taxes and Comprehensive Tax Reform, in Uneasy Compromise: Problems of A HYBrid InCOME-CONSUMPTION TAX (Henry J. Aaron et al. eds., 2010).

${ }^{141}$ See, e.g., Desai \& Dharmapala, supra note 96.
} 
compared to that of net income. So the question from the start is how one should respond to what one deems the potential overuse of deductible payments to foreign affiliates — not whether they are ever appropriate adjustments under a tax system that employs separate entity accounting. ${ }^{142}$

2) Because MNCs may be more mobile than purely domestic companies, there are plausible arguments for taxing them at lower effective rates. ${ }^{143}$ If modified taxable income were a reasonable proxy for economic income, then the BEAT's allowing MNCs to reduce their U.S. tax rates from twenty-one percent to ten percent, but no further, might be rationalized as helping to ensure that the tax burdens would be, from this standpoint, "just right," rather than either too high or too low. "Given, however, that modified taxable income generally is not a plausible proxy for true U.S.-source economic income, this line of defense for the BEAT's minimum tax structure is unavailing." 144

3) The fact that modified taxable income is not itself a plausible freestanding tax base encourages viewing the BEAT's minimum tax structure as fundamentally unmotivated. Instead, one might more fruitfully view it as effectively a two-tier excise tax on base erosion tax benefits that thereby adjusts their overall MRR. From that perspective, a logical starting point would be to consider subjecting

\footnotetext{
${ }^{142}$ Some recent international tax reform proposals would involve generally neither including nor deducting cash flows between affiliates, without thereby moving towards the taxation of gross income in a particular jurisdiction. See Shaviro, supra note 120 at 51-53.

${ }^{143}$ See, e.g., Daniel Shaviro, The New Non-Territorial U.S. International Tax System, Part 1, TAX Notes, July 2, 2018 at 57, 63 \& n. 43 (citing Frank P. Ramsey, A Contribution to the Theory of Taxation, 37 Econ. J. 47, 58 (1927)).

${ }^{144}$ Shaviro, supra note 125 at 175.
} 
base erosion tax benefits (if they remain the exclusive focus) to a single flat rate of excise tax-or equivalently, making them uniformly less than one-hundred percent deductible. ${ }^{145}$ The analysis would then turn to asking whether there are any reasons for varying the excise tax rate based on broader taxpayer characteristics - at the cost of creating clienteles, but potentially to be rationalized if it uses relevant information to improve the provision's targeting.

\section{Summing Up}

When a technical minimum tax meets the purposive standard of truly broadening, rather than just expanding, the tax base, this has implications for how one might adapt it if concerned about the downsides from its applying at the margin only selectively. A purposive minimum tax might plausibly wholly replace the regular tax, or at least have a tax rate that is almost as high. This becomes less appealing, however, when the larger base, like that of the BEAT, clearly over-measures economic income in some respects.

Suppose one could replace the BEAT, on a revenue-neutral basis, with a fixed-rate excise tax that raised the same revenue. Whether or not this would be a good tax instrument as compared to all conceivable alternatives, it would have a strong chance of being superior to the BEAT. For one thing, it would smooth out the BEAT's discouragement of base erosion tax benefits to have a steadier excise tax rate structure than one that jumps suddenly from 0 percent to 21 percent. Adopting a flatter excise tax rate structure could also smooth out the BEAT's clientele effects, without necessarily changing its aggregate impact on

\footnotetext{
${ }^{145}$ For example, if the regular corporate tax rate is twenty-one percent, applying a seven percent excise tax to base erosion tax benefits is generally equivalent to making them two-thirds deductible. See id. at 176 .
} 
efforts to reduce reported DSI. ${ }^{146}$ More generally, an excise tax-based way of thinking about the underlying BEAT concerns of transfer pricing abuse and over-concentrating deductible intra-group payments in high-tax jurisdictions seems likely to be more constructive than AMT-style thinking. ${ }^{147}$

${ }^{146}$ As I have argued elsewhere, other seemingly arbitrary BEAT features, such as its disregarding payments that constitute cost of goods sold, its three percent rule, and its surprisingly high size threshold for applicability, might also be "traded in" on a revenue-neutral basis for its applying more uniformly at a lower nominal rate. See Shaviro, supra note 125 at 194.

${ }^{147}$ This ignores possible strategic reasons for using an approach like that of the BEAT. See, e.g., Itai Grinberg, The Senate Introduced a Pragmatic and Geopolitically Savvy Inbound Base Erosion Rule 5 (Working Paper, 2017), https://papers.ssrn.com/sol3/papers.cfm?abstract_id=3069770 (arguing that the BEAT might have advantages from the standpoint of treaty compatibility and limiting feasible retaliation). 


\section{LOSS NONREFUNDABILITY AND FOREIGN TAX CREDIT LIMITATIONS}

As noted earlier, loss nonrefundability and FTC limitations are not technical minimum taxes, since their application does not involve comparing one's tax liability under distinct "regular" and "alternative" systems. Instead, they create discontinuity with respect to the marginal value derived from the targeted tax benefits within a single system (i.e., the regular tax). This reflects the lack of any need for an alternative income computation when the tax benefit that is being rationed pertains, not to computing taxable income, but rather to determining its liability consequences for the taxpayer.

Loss nonrefundability and FTC limitations nonetheless have enough in common with technical minimum taxes, and with each other, to motivate analyzing them here. Relevant aspects of their application include the following:

1) Just as an AMT prescribes the minimum permissible tax liability given one's AMTI, so loss nonrefundability establishes a floor on annual tax liability of zero, as distinct from permitting negative tax liability. ${ }^{148}$ Similarly, FTC limitations prevent tax liability with respect to FSI from turning negative, as could happen even without refundability if FTCs could offset the taxes attributable to DSI. The fact that the two sets of rules set a tax rate or tax liability floor of zero, rather than requiring some positive amount-thus semantically altering their character for those who view positive and negative numbers asymmetrically—does not prevent them from raising many of the same issues as technical and semantic minimum taxes.

\footnotetext{
148 The 2017 tax act further limited the use of net operating losses (NOLs) by preventing their use to offset more than eighty percent of one's taxable income as otherwise determined. Tax Cuts and Jobs Act, Pub. L. No. 115-97 § 13302 (amending I.R.C. § 172(a)).
} 
2) For example, even without the technical minimum tax feature of separate yet interacting tax systems, nonrefundability and FTC limitations cause the tax consequences associated with a given item to depend, not just on its stand-alone treatment, but on how it interacts with other items, thus causing the tax consequences of particular choices to depend on the overall composition of the taxpayer's assets or activities.

3) Nonrefundability and FTC limitations therefore share two of the main downsides of using an AMT to address the items that it disfavors. They both induce taxpayers to pay otherwise pointless heed to the numerical relationship between "good" and "bad" items, and create distinct clienteles based on where one stands at the margin.

Loss nonrefundability would be hard to rationalize persuasively if one were confident that the tax system measured economic income accurately. Ex ante, it "penalize[s] risk-taking by undiversified investors." ${ }^{149}$ Ex post, its reach extends to true economic losses that make one worse-off than if one had managed to break even. Yet, even with concern about mismeasurement, it raises the question of why the chosen response would be discontinuous, in the sense of having no impact until one reduces taxable income to zero, at which point (for corporations) it lowers the current year MRR for deductions from 21 percent to zero.

FTC limitations raise similar issues. However uneasy one might rightly be about FTCs' offering a 100 percent MRR for foreign tax payments that go to foreign sovereigns rather than the domestic one, discontinuously changing the current year MRR to zero percent after the last penny of domestic taxes otherwise due on FSI has been offset is not an obviously optimal response.

${ }^{149}$ Daniel N. Shaviro, Selective Limitations on Tax Benefits, 56 U. CHI. L. REV. 1189, 1256 (1989). 
In each case, there are two main responses that one could offer in defense of the existing rules. The first is that the semantics of the number zero provide an opportunity to limit FTCs and potentially noneconomic deductions that would not otherwise be available. This offers a political economy rationale for the rules, if one both accepts the underlying empirical claim about unfeasibility of "trade-ins" and believes that the tax rules concerning FTCs and/or deductions would otherwise be too generous. As in the AMT case, however, such an argument for the limitations is subject to the further question of whether any such advantages outweigh the usual costs, such as from creating tax clienteles that may lead to inefficient resource allocation.

Second, both rules could be defended by reference to a substantive aspect of relying on the number zero. Suppose that, absent loss nonrefundability, taxpayers could use lossgenerating tax shelters to generate potentially unlimited net transfers from the Treasury. ${ }^{150}$ Preventing them from using the shelters to drive net tax liability below zero might conceivably offer a relatively straightforward constraint on how far this game can go. For FTC limitations, a parallel argument would rest on concern about taxpayers using what the IRS labeled as "foreign tax credit generator transactions"151 to wipe out the taxes that would otherwise be due, not just on FSI, but also on DSI, and indeed going beyond that if excess FTCs were directly refundable.

\footnotetext{
${ }^{150}$ See, e.g., Daniel Shaviro, The Story of Knetsch, in TAX Stores 351 (Paul L. Caron ed., 2nd ed. 2009) (noting that "pure tax arbitrage" transactions can potentially be used to generate unlimited tax losses).

${ }^{151}$ See Kevin Dolan, The Foreign Tax Credit Generator Regs: The Purple People Eater Returns, 115 TAX NOTES 1155 (2007).
} 
4) Conceptually and practically similar to nonrefundability and to the FTC limitation, although not similarly relying on the semantics of the number zero, are various tax provisions that limit particular deductions relative to some larger income measure. For example:

--Certain charitable deductions cannot exceed 30 percent or 50 percent, as the case may be, of the taxpayer's adjusted gross income. ${ }^{152}$

--Leaving aside the temporary effects of the Coronavirus Aid, Relief, and Economic Security (CARES) Act, NOLs generally cannot be used to offset more than 80 percent of current year taxable income, ${ }^{153}$ and deductions for business interest cannot exceed 30 percent of "adjusted taxable income."154

Such provisions may differ from nonrefundability and FTC limitations in such dimensions as their rationales or their optical effects. Yet they also occupy much common ground. For example, they may similarly create tax clienteles and discontinuous marginal incentives, by reason of their causing an item's tax effects to depend on its interaction with other items. Thus, while I will not further discuss them here for reasons of length, a common analysis would clearly be merited.

\footnotetext{
${ }^{152}$ See I.R.C. § $170(b)$.

${ }^{153}$ I.R.C. § 172(a)(2).

${ }^{154}$ I.R.C. $§ 163(\mathrm{j})$.
} 


\section{Foreign TaX CRedit Systems ANd Global Minimum TaXes}

In international tax policy debate, global minimum taxes are currently having their moment. ${ }^{155}$ What will come of this moment remains unclear, but two recent developments have helped to place them high on the agenda. ${ }^{156}$ The first was the 2017 U.S. adoption of GILTI, and the second was the OECD's promulgating a preliminary global minimum tax proposal in "Pillar Two" of its GloBE initiative. ${ }^{157}$

Given how global minimum taxes interact domestic with foreign tax liability, they impose two distinct minimum rates - not just one. To illustrate, suppose that a country imposes a fifteen percent global minimum tax on resident MNCs' FSI, requiring them to pay the excess, if any, of the amount thus computed over their foreign tax liabilities. Under what I will call the global revenue perspective, they face a minimum fifteen percent global rate on their FSI. Under what I will call the national revenue perspective, they face a minimum zero percent domestic rate on their FSI. After all, an MNC with, say, a twenty percent global rate does not get to reduce this to fifteen percent via a domestic rebate of the excess.

This Part first describes leading global minimum tax provisions and proposals, including pre-2017 U.S. law despite its semantic exclusion from the minimum tax family.

\footnotetext{
${ }^{155}$ See e.g., Aaron Junge et al., Design Choices for Unilateral and Multilateral Foreign Minimum Taxes, TAX NOTES FED., Sept. 2, 2019 at 1525, https://www.taxnotes.com/tax-notes-today-federal/internationaltaxation/design-choices-unilateral-and-multilateral-foreign-minimum-taxes/2019/09/17/29vng; MiCHAEL P. DevereuX eT AL.; OXford University Centre for Business TaXATIOn, The OECD Global ANTi-Base EROSION PROPOSAL (2020), https://www.sbs.ox.ac.uk/sites/default/files/202002/OECD_GloBE_proposal_report.pdf; Amanda Athanasiou, Minimum Tax Should Be a Global Priority, French Council Says, TAX Notes InT'L, Nov. 25, 2019 at 728, https://s3.amazonaws.com/pdfs.taxnotes.com/2019/2019tni47-16.pdf. See also, H.R. 6015, 115th Cong. (2018) (proposing to modify GILTI to impose a per-country minimum tax).

${ }^{156}$ See Junge et al., supra note 155 at 1526.

${ }^{157}$ OECD, supra note 13 at 5-7 (discussing the elements of the Pillar Two proposal).
} 
It then considers how a given country's unilateral or strategic pursuit of its national welfare (defined in terms of its residents' wellbeing) might influence the choice of MRR for foreign taxes paid. Finally, it considers the implications of an MRR analysis for the use (or not) of a minimum tax structure.

A. Global Minimum Taxes and the Surrounding Neighborhood

\section{The Global Minimum Tax Character of the Pre-2017 U.S. International Tax Regime}

As noted earlier, pre-2017 U.S. international tax law could have been-but generally was not-viewed as imposing a global minimum tax on U.S. MNCs' FSI, as measured for U.S. tax purposes. ${ }^{158}$ Under a global revenue perspective, it imposed a thirtyfive percent minimum worldwide rate. Under a national revenue perspective, it imposed a zero percent minimum domestic rate.

Why, then, was this system not generally viewed as imposing a global minimum tax? As noted earlier, from a domestic revenue perspective, the semantics of the number zero stood in the way. From a global revenue perspective, the policymakers' intent did so. The United States had started out by simply taxing FSI at the full domestic rate, without otherwise distinguishing between DSI and FSI, and with no special adjustment for foreign taxes paid. This was neither a minimum tax of any kind, nor reflective of any judgment regarding FSI's distinctive character. But even when the FTC was added to the Code in $1918,{ }^{159}$ followed by the FTC limitation in $1921,{ }^{160}$ — thus creating what we today can

\footnotetext{
${ }^{158}$ See supra notes $29-30$ and accompanying text.

${ }^{159}$ Revenue Act of 1918, ch. 18. §§ 222(a)(1), 238(a), 240(c), 40 Stat. 1057,1073, 1080-82 (1919); see also Michael J. Graetz \& Michael M. O'Hear, The "Original Intent" of U.S. International Taxation, 46 DuKE L.J. 1021, 1043-53 (1997) (discussing the Revenue Act of 1918).

${ }^{160}$ Revenue Act of 1921, ch. 136, §§ 222(a)(5), 238(a), 42 Stat. 227, 249, 258; see also Graetz \& O’Hear, supra note 159 at $1054-58$.
} 
recognize as a global minimum tax-it should come as no surprise that a modern terminology did not precociously emerge. The FTC regime's enactment was an inwardlooking exercise, aimed at avoiding what the proponents deemed "unfair" double taxation of “our” taxpayers' FSI. It was not, like today's avowed global minimum taxes, aimed at such distinctively global concerns as, say, tax havens' effect on tax competition. The modern prototypes' being, by contrast, precisely so aimed is made clear, not just by the surrounding rhetoric, but also by their use of a minimum global rate that differs from the tax rate on DSI. This helps to focus attention on the proposals' distinctively addressing global concerns, rather than simply applying domestic law to FSI.

One important aspect of pre-2017 U.S. international tax law, not retained in more recent global minimum taxes, was that it applied a rule called deferral when computing MNCs' FSI. Under deferral, U.S. companies generally did not owe U.S. tax on profits they had earned abroad through controlled foreign corporations (CFCs) until the profits were repatriated for U.S. tax purposes, such as through the receipt of a dividend. ${ }^{161}$ Deferral did not merely narrow the U.S. tax base, relative to the case of its including all FSI earned (whether directly or indirectly) by U.S. corporate parents. In addition, it greatly modified the incentives that the system created.

Thus, under pre-2017 law, consider a U.S. firm that was evaluating its economic sensitivity to foreign taxes. If all FSI had been currently taxable in the U.S., the firm would be unaffected by whether such taxes were high or low, so long as FTC limitations did not apply. By contrast, under deferral, U.S. companies had much wider-ranging economic

\footnotetext{
${ }^{161}$ See Craig M. Boise, Breaking Open Offshore Piggybanks: Deferral and the Utility of Amnesty, 14 GEO. MASON L. Rev. 667, 667 \& n. 2 (2007); David S. Gallichio, Reenacting the Repatriation Holiday: Can I.R.C. § 965 Incentivize Green Investment?, 26 Tulane ENVTL. L.J. 313, 316-17 (2013).
} 
incentives to be cost-conscious with respect to their foreign tax liabilities. For example, if they anticipated never repatriating the funds for U.S. tax purposes (at least, until such time as the repatriation tax had been repealed), they would never get to claim the FTCs, and thus would never get effectively reimbursed by the U.S. Treasury. A lesser version of this scenario applied even if they merely anticipated the enactment of lower (but not zero) repatriation tax rates in the future. ${ }^{162}$

Had deferral not existed, all stably excess-limit firms would have formed a clientele that was wholly indifferent to foreign tax liabilities, in contrast to excess-credit firms that would have reason to be foreign tax cost-conscious. Deferral, however, caused firms that could sufficiently delay (and, as needed, optimally time) their taxable repatriations to be foreign tax cost-conscious as well. This significantly changed the clienteles' composition, without putting them out of existence. ${ }^{163}$

\section{Pre-2017 U.S. Global Minimum Tax Proposals}

Prior to the 2017 U.S. tax act, there was considerable discussion among U.S. policymakers of replacing the U.S. international tax system with one in which U.S. companies' FSI would indeed have faced what proponents called a minimum tax. For example, “the Obama Administration's fiscal 2016 and 2017 budgets included a proposal to adopt ... a 19 percent per-country minimum tax on some foreign income earned by U.S.

\footnotetext{
${ }^{162}$ See Daniel N. Shaviro, Fixing U.S. International Taxation 83-86 (2014).

${ }^{163}$ Indeed, rather than there being two internally uniform clienteles, taxpayers might differ relatively continuously with respect, for example, to the likelihood of facing a taxable repatriation or of being able to use FTC carryovers.
} 
corporations directly or through $\mathrm{CFCs"164}$ (i.e., FSI as defined without regard to deferral). Similar proposals emerged from the leadership of the House and Senate tax committees. ${ }^{165}$ As described so far, this would not have altered the global minimum tax character of U.S. international tax law. The Obama Administration proposal retained a minimum permissible tax rate on FSI of zero percent from a national revenue perspective, while merely lowering it from thirty-five to nineteen percent from a global revenue perspective. ${ }^{166}$ The proposal also would have lowered the domestic corporate tax rate from 35 percent to 28 percent.

In substance, the proposal would actually have reduced the minimum tax character of then-existing U.S. international tax law. It would have treated foreign taxes as only eighty-five percent creditable, rather than one hundred percent. ${ }^{167}$ Accordingly, while the minimum global tax rate for a U.S. MNC's FSI was nineteen percent if it paid no foreign taxes, this rose to about 22.35 percent as its foreign tax liabilities increased. ${ }^{168}$ There

\footnotetext{
164 Junge et al., supra note 155 at 1528; DeP'T TrEasury, GENERAL EXPlanAtions of THE AdMINISTRATION'S FisCAL YEAR 2016 REVENUE PROPOSALS 20-22 (2016) (“Under the proposal, the foreign earnings of a CFC or branch or from the performance of services would be subject to current U.S. taxation at a rate (not below zero) of 19 percent less 85 percent of the per-country foreign effective tax rate (the residual minimum tax rate)."); see also OfF. MGMT. \& BUDGET, BUDGET OF THE U.S. GOVERNMENT: FISCAL YEAR 201751 (2016) ("The Budget details the President's full plan for reforming and modernizing the international business tax system, including a 19 percent minimum tax on foreign earnings ....”).

${ }^{165}$ See Baucus, supra note 11; FERRELL et al., supra note 14.

166 The proposal's applying the foreign tax credit limitation on a per-country, rather than an aggregate basis, was not novel, as this approach had featured in U.S. law from 1932 through 1976. See Philip R. West \& Amanda P. Varma, The Past and Future of the Foreign Tax Credit, TAXES, Mar. 2012, at 27, 29.

${ }^{167}$ DeP'T TREASURY, supra note 164 at 20 (2016) (describing the eighty-five percent FTC not as an FTC, but simply a reduced residual domestic tax liability by reason of the foreign taxes paid).

${ }^{168}$ With 85 percent creditability, one would need to pay just over 22.35 percent in a given country in order to have enough credits to offset wholly the 19 percent U.S. rate. I state this in per-country terms because the proposal, unlike then-existing law, would have applied FTC limitations on a per-country, rather than an aggregate, basis. $I d$. (describing the minimum tax rate as imposed on a country-by-country basis, not in aggregate across all FSI).
} 
accordingly was a sliding scale with respect to required minimum global tax liability, rather than a single fixed rate.

Why, then, was the Obama Administration proposal commonly called a global minimum tax, whereas then-existing law was not? Disallowing deferral, while important substantively, might reasonably have been deemed irrelevant semantically. After all, it merely affected how FSI would consistently be defined from both a national and global standpoint. But the aim of addressing global tax competition was now front and center, and highlighted by the proposal's applying a lower U.S. tax rate to FSI than DSI.

\section{GILTI}

GILTI is essentially just a variant of the Obama Administration's global minimum tax proposal. Among its main differences from that proposal are the following:

1) GILTI's marginal tax rate for FSI is 50 percent of the contemporaneous corporate rate for DSI (i.e., 10.5 percent rather than 21 percent), rather than being just below 68 percent (i.e., 19 percent divided by the new proposed general corporate rate of 28 percent). ${ }^{169}$

2) GILTI offers an 80 percent FTC for foreign taxes paid, in lieu of 85 percent. ${ }^{170}$ Thus, from a global revenue perspective, the minimum permissible tax rate rises from 10.5 percent to a 13.125 percent as one's foreign effective tax

\footnotetext{
${ }^{169}$ GILTI's marginal tax rate is fifty percent of the prevailing corporate rate on DSI, because Section 250(a) provides a fifty percent deduction on GILTI. I.R.C. $§ 250$ (a)(1)(B)(ii).

${ }^{170}$ I.R.C. $\S 78$ (grossing up FSI to include the deemed amount of foreign taxes paid); I.R.C. $\S 960$ (d) (permitting a FTC only for eighty percent of deemed foreign taxes on GILTI).
} 
increases from zero. ${ }^{171}$ (From a national revenue perspective, the minimum permissible tax rate continues to be zero.)

3) GILTI's minimum rate applies to overall FSI, rather than on a separate country-by-country basis. ${ }^{172}$

4) For purposes of determining whether the requisite rate has been paid, GILTI exempts from FSI a 10 percent deemed return on tangible business property used abroad. ${ }^{173}$

5) GILTI does not permit FTC carryovers, thus creating harsh annual accounting effects that the Obama Administration proposal had sought to avoid. ${ }^{174}$

Both GILTI and its Obama Administration prototype, by offering less than 100 percent foreign tax creditability, reduce the frequently bimodal character of the distinction between minimum taxes and stand-alone tax instruments. Suppose that one gradually modified GILTI by reducing the FTC percentage from 80 percent to zero. There would be no bright line point at which it suddenly jumped ship from being a minimum tax to being a separate instrument. Even if one drew the line here semantically at, say, 50 percent creditability, this would create a terminological boundary between hypothetical GILTI

\footnotetext{
17180 percent of 13.125 percent equals 10.5 percent; Hence, at this or a higher rate, one's FTCs wholly eliminate the residual U.S. liability under GILTI.

172 I.R.C. § 951(c) (defining GILTI and "net CFC tested income" without regard to country-by-country reporting).

${ }^{173}$ I.R.C. $\S 951$ (b) (deducting an imputed ten percent return on the "aggregate of such shareholder's pro rata share of the qualified business asset investment" in calculating GILTI).

${ }^{174}$ See Junge et al., supra note 155 at 1530-1532 (listing these five items plus other GILTI features that depart from those in the Obama Administration's global minimum tax proposal).
} 
variants (e.g., those with 51 percent versus 49 percent creditability) that differed in substance only minimally. We will see that this point has implications for whether a "minimum tax" is really the right instrument or label for addressing or describing policymakers' concerns.

\section{Pillar Two of the OECD's GloBE Proposal}

Apparently inspired to a degree by GILTI, ${ }^{175}$ the OECD in 2019 offered its own global minimum tax discussion model, in Pillar Two of its ongoing anti-base erosion initiative. The proposal's preliminary and exploratory character reflects, not just the need to develop consensus among member nations, but also the particular design challenges posed by a proposal that is meant for multilateral adoption.

Consider, for example, how one defines FSI for purposes of the rule. GILTI's drafters could simply rely on U.S. tax law. In a multilateral instrument, however, one must either accept national differences that could undermine the aim of consistent application, or specify a common tax base for this purpose. ${ }^{176}$ Likewise, GILTI's drafters could set the global minimum tax rate with an eye to how they wished it to relate to the U.S. corporate rate for DSI. In the multilateral context, however, not just countries' domestic corporate rates, but the global minimum rates that they are willing to contemplate may vary. ${ }^{177}$

\footnotetext{
${ }^{175}$ See, e.g., Daniel Bunn \& Elke Asen, Tax Foundation Response to OECD Public Consultation Document: Global Anti-Base Erosion Proposal ("GloBE") (Pillar Two), TAX Found. (Dec. 2, 2019), https://taxfoundation.org/response-global-anti-base-erosion-pillar-two-proposal.

${ }^{176}$ One possibility that the OECD raises is to base the common measure on financial accounting income, although this too may vary definitionally between jurisdictions. See OECD, supra note 13 at 31 .

177 See id. at 29-32.
} 
While the OECD deliberately leaves open-ended both these and further critical design questions, ${ }^{178}$ it appears to contemplate a GILTI-like structure, in which an MNC's country of residence would impose a "top up to a minimum rate" with respect to its CFCs' FSI. ${ }^{179}$ This suggests the equivalent of 100 percent, rather than 80 percent, FTCs - a feature that, as I discuss below, presumably reflects its hoped-for multilateral character.

\section{B. Choosing MRRs for Resident MNCs' Foreign Tax Liabilities}

Both global minimum taxes and FTCs (with or without FTC limitations) raise a fundamental underlying question: What sort of MRR for foreign taxes does it make sense for a given country to adopt? This question is best addressed first unilaterally, or under the simplifying assumption that no other country's actions will be affected by what one does; and then strategically, or with regard to what such effects might be. Multilateral adoption of a uniform global rule, based on interdependent consent, is just one possibility within the strategic realm, and not necessarily to be presumed.

1) Simple unilateral analysis: A starting point for the unilateral analysis rests on the simple observation that, when taxes are paid to the domestic sovereign, "we" (that is, domestic citizens or residents) presumably get the use of the money. By contrast, when taxes are paid to a foreign sovereign, "we" do not get the money. Instead, it goes to the taxing country's citizens or residents. The former of these two cases underlies the standard

\footnotetext{
${ }^{178}$ For example, the OECD does not aim to specify at this stage the extent to which its global minimum tax would allow "blending," defined as "the ability of taxpayers to mix high-tax and low-tax income to arrive at a blended rate on income that is above the minimum rate." Id. at 32. This is the issue raised, for example, by the distinction between the Obama Administration proposal's applying country-by-country limitations, and GILTI's application on an overall global basis. The OECD also notes the possibility of GloBE, like GILTI, excluding a return on tangible assets. $I d$.

${ }^{179}$ See id. at 30, 32. However, various special rules might also apply, such as additional inclusions where FSI benefited from a "harmful preferential regime," along with possible carve-outs for regimes that were deemed benign. Id. at 32 .
} 
assumption in the tax policy and public finance literatures that, from a social standpoint, tax payments are transfers rather than costs, ${ }^{180}$ although to taxpayers they are the latterthus causing tax planning to be, in the main, socially wasteful. ${ }^{181}$

Payments to foreign sovereigns lack this feature of inuring to "our" benefit. From a selfish national welfare standpoint, this would suggest - assuming there are no other relevant considerations - treating foreign tax payments, like any other cost incurred in the course of earning income (such as for employee wages or office rent) as merely deductible. ${ }^{182}$ Or, to put it another way, the MRR for foreign taxes should equal the marginal tax rate (MTR) for the associated income. ${ }^{183}$ This rate is zero percent if the associated FSI is not subject to domestic tax.

2) Complicating the unilateral analysis: If the above analysis captured all relevant considerations apart from strategic ones, the unilateral case for a global minimum tax (as well as for offering FTCs) would be verging on unfathomably weak. Suppose that individuals who were among "us" earned FSI, either directly or through resident corporations, and paid no domestic tax on it. Even if this was considered undesirable from

\footnotetext{
${ }^{180}$ See, e.g., Jonathan Gruber, Public Finance and Public Policy 590-600 (3d ed., 2011).

${ }^{181}$ See e.g., Philip A. Curry et al., Creating Failures in the Market for Tax Planning, 26 VA. TAx L. REV. 943, 944 (2007) ("Governments expend costs to collect taxes; people expend resources to avoid paying them, engaging in tax planning activities that are, for the most part, socially wasteful."); David A. Weisbach, Disrupting the Market for Tax Planning, 26 VA. TAX L. REV. 971 (2007)

${ }^{182}$ See Fadi Shaheen, International Tax Neutrality: Reconsiderations, 27 VA. TAx L. REV. 203, 205, 209-10, 234-36 (2007); see also Peggy B. Musgrave, United States TAXation of Foreign InVESTMENT Income 134 (1969); Joel B. Slemrod, Free Trade Taxation and Protectionist Taxation, 2 InT'L TAX \& PUB. FIn. 471, 479 (1990).

${ }^{183}$ From this standpoint, merely having an MRR below one-hundred percent (so that there is some costconsciousness with respect to foreign taxes) is not enough. The government will want the taxpayer to view foreign taxes interchangeably with other costs the taxpayer might incur and thereby try to maximize afterforeign-tax income.
} 
a national welfare standpoint—based, for example, on FSI's increasing such individuals' ability to pay - their paying foreign taxes on the FSI would offer no direct mitigation. Instead, it would merely make "us" collectively poorer, and the foreign taxes' foreign beneficiaries richer.

Perhaps the unilateral analysis so far is missing something, however. Countries commonly subject resident taxpayers (including MNCs) to anti-tax haven rules of greater or lesser rigor. The existence of these may cause the foreign taxes that MNCs incur when they do not report FSI in tax havens - thereby allowing them to avoid being adversely affected by the rules - to be, in effect, better than deductible, and perhaps even better than creditable. For example, as I have noted elsewhere, "suppose that paying \$20 (rather than zero) in foreign taxes on $\$ 100$ of [FSI] would permit a resident MNC to eliminate $\$ 21$ of domestic tax liability under a particular CFC rule. In effect, those foreign taxes face a 105 percent MRR." "184

The widespread use of anti-tax haven rules appears to reflect the view that foreignto-foreign tax planning, which MNCs use to locate FSI in tax havens, is complementary with their also engaging in what is considered excessive profit-shifting at the expense of the domestic tax base. ${ }^{185}$ This, in turn, suggests that the unilaterally optimal MRR for MNCs' foreign taxes might be higher than the MTR that applies to their FSI, even if one agrees that it should generally be lower than one-hundred percent (in order to retain some cost-consciousness at this margin). Unfortunately, however, the question of what the MRR for foreign taxes should be, even in a purely unilateral analysis, presents what I have called

\footnotetext{
${ }^{184}$ See Shaviro, supra note 143 at 68.

${ }^{185}$ See id. at 67.
} 
a "Goldilocks problem." This term adverts to the choice faced by the little girl in the Three Bears fairytale who must subjectively decide, without the benefit of any generally applicable choice metric, whether a given cup of porridge is too hot, too cold, or just right. ${ }^{186}$

3) Adding strategic considerations to the analysis: Foreign tax MRRs are a quintessential area for expecting strategic issues to be analytically significant. After all, one's treatment of one's MNCs' foreign tax liabilities not only may affect other countries' welfare, as an input to the MNCs' tax sensitivity, but does so fairly bluntly and directly. Thus, a game-theoretic analysis seems likely to be appropriate. Unfortunately, however, game theory's capacity to yield greater clarity concerning choices of foreign tax MRRs may often prove disappointingly limited.

An initial problem—albeit, hardly an unusual one for real world game theoretic analyses - is that the likely magnitude of the effect on other countries' decisions may depend on the broader strategic context. Suppose, for example, that during the era when most countries had at least nominally worldwide systems with FTCs, one had unilaterally decided to make the taxes that resident MNCs' earned abroad on FSI merely deductible, while otherwise keeping things the same. It is plausible that this would have risked triggering retaliation in kind, such as the denial of FTCs with respect to one's source-based taxation of foreign MNCs.

\footnotetext{
${ }^{186}$ See The AnNotated Classic Fairy Tales 245-52 (Maria Tatar ed., 2002) (providing both the history of Goldilocks in "The Story of the Three Bears" and a retelling). To be sure, Goldilocks herself does not appear to require any generally applicable choice metric in order to classify particular cups of porridge with great self-confidence.
} 
By contrast, suppose that, during the era of predominantly worldwide taxation, one had shifted to a more territorial system in which most FSI was taxed at zero percent and foreign taxes therefore generally ignored (i.e., reimbursed at zero percent, causing them to be implicitly deductible). ${ }^{187}$ Here, the optical effects changing one's international tax system more broadly might greatly lower the prospect of targeted strategic retaliation. It is, however, plausible that the shift would increase the likelihood of other countries' similarly (and in the nearer term than otherwise) changing their tax systems - a possibility that would need to be incorporated (whether as a positive or a negative) into a full strategic analysis.

Finally, suppose one is a late mover in the shift from greater use of FTCs to greater use of exemption for FSI, at a point when it has become nearly general. Then it would be unsurprising if the relevant strategic effects proved to be smaller than in the immediately preceding example.

Such issues alone should not make a strategic analysis intractable. A further problem, however, pertains to how one evaluates alternative outcomes. In a classic prisoner's dilemma, we understand that each "player" wants to minimize its "prison time" (i.e., the loss of welfare that it would experience under different resolutions). In the international tax policy realm, however, there is fundamental dissensus regarding how to evaluate different international tax regimes' national welfare effects, even unilaterally. ${ }^{188}$ Leading scholars commonly disagree about the desirability, not just of higher versus lower MRRs for foreign taxes, but also with regard to such often linked issues as whether the tax

\footnotetext{
187 See e.g., Shaviro, supra note 162 at 49-50, 84, 187 (discussing how foreign taxes are implicitly deductible under territoriality).

${ }^{188}$ See Daniel Shaviro, 10 Observations Concerning International Tax Policy, TAX Notes, June 20, 2016 at 1705-1706.
} 
rates on FSI should be high or low, and whether CFC rules should be more stringent or more lenient. Hence, I have elsewhere called international tax policy an "ongoing N-person game in which no one agrees about the underlying payoff structure."189

Despite these problems, perhaps a few cautious conclusions can be reached. One is that strategic considerations seem more likely to raise than lower the MRR that one should offer for foreign taxes, given the possibility that other countries will play tit-for-tat. A second is that, even if there were consensus regarding how to evaluate the unilateral national welfare effects of particular international tax regimes, it seems likely that these will vary by country. For example, countries with higher tax rates and more outbound investment by resident corporate entities might have reason to favor higher MRRs than other countries. Given the sheer number of countries whose international tax regimes may have spillover effects on other countries, this adds to the OECD's challenge in seeking to craft a global minimum tax that will attract widespread support.

C. MRRs and the Use of a Global Minimum Tax Structure

Suppose one defines a pure global minimum tax as having two main features. First, it offers a one-hundred percent foreign tax MRR until one eliminates the residual domestic tax liability with respect to FSI. At that point, the MRR switches to zero percent, leaving aside the possible impact of multiyear averaging. Second, it applies globally to FSI, like GILTI, rather than on a country-by-country basis, like the Obama Administration proposal, thus increasing (as shown below) the extent to which it is minimum tax-like.

1) MRR of one hundred percent, then zero percent: Neither of these MRRs seems likely to be optimal from a domestic national welfare standpoint. A one hundred

${ }^{189} \mathrm{Id}$. at 1705 . 
percent MRR eliminates all resident MNC cost-consciousness with respect to foreign taxes paid. Moreover, even if the MRR were slightly below one hundred percent, inducing some marginal cost-consciousness, resident MNCs would still have reason substantially to prefer foreign tax liabilities to other liabilities or forgone gross income. Assuming ownership of such MNCs by resident individuals, this is adverse to national welfare under the simple unilateral story. Its compatibility with national welfare under the more complicated unilateral story, or under a strategic one, requires particular justification and cannot simply be assumed. Proponents of global minimum taxes do not always appear to understand this. ${ }^{190}$ There also is no obvious rationale for switching from a one hundred percent MRR to one of zero percent in the manner provided. These oddities are accompanied, as is usual in the minimum tax setting, by the creation of tax clienteles and tax planning incentives around the switchover point.

2) Global, rather than per-country, minimum tax: Four key points about the choice between a global and a per-country minimum tax are as follows. First, in practice it is often a proxy for how lenient versus tough one wants one's global minimum tax to be. This reflects the fact that, all else equal, a per-country minimum tax is far more restrictive, because one cannot average between the taxes on FSI reported in high-tax versus low-tax countries in order to avoid domestic tax liability with respect to the latter. It thus comes as

\footnotetext{
${ }^{190}$ See, e.g., Grubert \& Altshuler, supra note 10. Grubert and Altshuler laud stand-alone U.S. adoption of a per-country global minimum tax (with expensing) against the background of pre-2017 U.S. international tax law. This reflects their listing a set of policy aims that does not include promoting efficiency at the margins emphasized in this article. They also, without discussion or explanation, generally follow a global, rather than a national, welfare perspective, even though they appear to be addressing U.S. policymakers. See id. at 682. The one exception to their ignoring the normative relevance of which country gets a given dollar of tax revenues arises when they briefly consider the possibility that other countries would respond to stand-zalone U.S. adoption of a fifteen percent by enacting "soak-up" taxes to transfer tax revenues from the United States to them. See id. at 697. Here they suggest - still without explaining the normative motivation - that this might offer support for U.S. adoption of something in the neighborhood of merely ninety-five percent creditability.
} 
no surprise that the Obama proposal (issued by a Democratic administration) used a percountry approach, while GILTI (drafted by Congressional Republicans) used a global approach. Democrats frequently support higher U.S. taxation of resident MNCs' FSI than do Republicans. ${ }^{191}$

Second, in principle the choice between per-country and global approaches ought not to be driven by preferences as to the instrument's stringency. It involves a structural design feature that might best be resolved based on its own merits. Other adjustments - for example, to the MRR, or else to how FSI is computed for purposes of the rule - can then be used to help one achieve the desired level of overall stringency.

Third, a per-country approach seems likely in practice to be significantly less "minimum tax-like" than a global approach. The essence of a minimum tax, giving rise to its creation of tax clienteles and tax planning incentives around the switchover point, is that it causes the marginal tax consequences of incurring a given item to depend on its relationship to other items on the tax return. This inevitably is brought to the fore, under a global limitation, when there is so much variation between countries' tax rates. By contrast, under a per-country approach, it is scaled back to involving only high-tax and low-tax items that were reportable in the same country.

If all items reported in a given country were taxed there in exactly the same way, one might view the per-country minimum tax as being that in name only. Suppose, for example, that both the statutory and effective tax rate incurred by U.S. MNCs for all items

\footnotetext{
${ }^{191}$ See, e.g., Naomi Jagoda, 2020 Democrats Set Sights on Corporate Tax Hike, THE HiLl (Oct. 27, 2019

7:21 P.M.), https://thehill.com/policy/finance/467549-2020-dems-set-sights-on-corporate-tax-hike (discussing various Democratic presidential candidates' plans to raise the corporate tax rate after it was reduced under Republican control).
} 
was ten percent in a hypothetical Assyria, and zero percent in a hypothetical Babylonia. Then, under GILTI as modified to apply on a per-country basis, the U.S. tax rate for U.S. MNCs' relevant $\mathrm{FSI}^{192}$ would simply be 0.5 percent in Assyria, and 10.5 percent in Babylonia. Since this would hold for all U.S. MNCs, they would not be in different clienteles from each other, nor would they be induced to manage the particular relationship between the FSI that they earn in Assyria versus Babylonia versus elsewhere.

Arguments can nonetheless be made for a global approach, relative to one of equal overall stringency that applies on a per-country basis. For example, the latter places greater pressure on determining and reporting the "true" source country for FSI It also might be criticized for "penalizing MNCs that 'naturally' (not just as a result of tax planning) split integrated production between particular higher-tax and lower-tax countries."193

Fourth, it is easier to rationalize a per-country approach than a global one as using relevant information to set the MRR properly, from a national welfare standpoint, with respect to particular items of FSI. Suppose that, as suggested by the anti-tax haven character of CFC rules, one views very low effective tax rates as being probabilistically associated with excessive profit-shifting at the expense of the domestic tax base. Then one may have reason to vary the domestic tax burden with respect to particular items of FSI, depending on the effective tax rates that they face abroad. Foreign tax MRRs may effectively be higher, as to high-tax versus low-tax countries, if a higher tax rate abroad leads to a lower domestic tax liability.

\footnotetext{
${ }^{192}$ I use the term "relevant FSI" to advert to such other aspects of GILTI's application as its exclusion of a ten percent deemed return on tangible business property. This rule would, of course, affect MNCs' incentive to limit tangible business property in Babylonia as opposed to Assyria, even with a per-country limitation.

${ }^{193}$ Shaviro, supra note 125 at 184.
} 
Given the problems associated with one hundred percent MRRs, however, a percountry approach need not involve anything especially close to the minimum tax side of the spectrum ranging from pure minimum taxes to purely separate instruments. Suppose one thinks of a per-country approach as simply involving the imposition of excise taxes on FSI that vary with the effective tax rate for a given country. Then one may have neither a purposive nor a technical minimum tax, but simply the use of relevant information to differentiate the treatment of FSI.

By analogy to other substantive areas discussed in this Article, this would be akin to treating the book-tax gap as offering relevant information, but nonetheless not using a minimum tax structure even if one is willing to assign tax consequences to book income. Likewise, it might be compared to replacing the BEAT with an excise tax rate for items such as base erosion tax benefits, without having the rate depend on their overall amount relative to regular taxable income. However, I will not attempt here to say more about how such a rule might be structured, or about its pluses and minuses relative to other types of CFC rules, such as those that impose residence-based taxation on passive FSI (by reason of its being deemed so easy to shift to tax havens). ${ }^{194}$

In sum, while there clearly are plausible rationales for treating resident MNCs' lowtaxed FSI less favorably than their high-taxed FSI, the case for doing so through a global minimum tax —or even an instrument close to it on the continuum, like GILTI—is uneasy at best. From a unilateral standpoint, persuasively rationalizing it would appear to require despair about the political or other feasibility of more nuanced alternatives. From a

\footnotetext{
${ }^{194}$ See, e.g., Shaviro, supra note 143 at 66.
} 
strategic standpoint, the case for it would appear to require relative optimism about its capacity to attract widespread multilateral support. But even in a fully multilateral setting, like that of the OECD if it had the capacity to broker general agreement to its recommendations, one must keep in mind minimum taxation's general drawbacks.

\section{CONCLUSION}

To a veteran of the 1986 tax reform, such as I am, the recent rise of interest in global and other minimum taxes induces feelings somewhere between déjà vu and nauseous regurgitation. In retrospect, the history of the AMT is not encouraging with regard to minimum taxes more generally, although some of the problems that it had were contextspecific. The basic logic behind relating two tax bases, or tax liability computations with respect to the same base, in the manner that results from employing minimum taxes, seems generally elusive. Relevant information conveyed by the relationship between two measures can potentially be used without either purposive or technical minimum taxation. The creation of discontinuous marginal incentives and of distinct tax clienteles, although not unique to minimum taxes, appear to be, at best, unfortunate byproducts of one's needing to advance broader policy aims under some set of constraints (such as political ones).

Bad though minimum taxes may generally be - at least, leaving aside the inevitable "compared to what?" question - there is every reason to expect that tax policy entrepreneurs will continue proposing them. The very term "minimum tax" connotes, whether accurately or not in particular cases, a small, easily managed adjustment to the overall tax system that most taxpayers can ignore due to a presumed rifle shot focus just on those among them who are paying less than a fair share. This may afford such proposals 
favorable political optics that may be hard to forgo, especially if more direct paths to a desired direction of policy change are unavailable.

Thus, it is plausible that minimum taxes should sometimes be used (or at least seriously considered), despite their drawbacks. Yet any such use should generally be contingent, reluctant, and based on understanding their structural deficiencies. 


\section{Oxford University Centre for Business Taxation Working Paper series recent papers}

WP20/03 Aqib Aslam and Alpa Shah Tec(h)tonic Shifts: Taxing the "Digital Economy" WP20/02 Ronald B. Davies, Dieter F. Kogler and Ryan Hynes Patent Boxes and the Success Rate of Applications

WP20/01 Richard Collier, Alice Pirlot and John Vella Tax policy and the COVID-19 crisis WP19/16 Alice Pirlot Don't blame it on WTO law: An analysis of the alleged WTO law incompatibility of Destination-Based Taxes

WP19/15 Irem Güçeri and Maciej Albinowski Investment Responses to Tax Policy under Uncertainty

WP19/14 David R. Agrawal and David E. Wildasin Technology and Tax Systems

WP19/13 Alice Pirlot Exploring the Impact of European Union Law on Energy and Environmental Taxation

WP19/12 Michael Devereux How should business profit be taxed? Some thoughts on conceptual developments during the lifetime of the IFS

WP19/11 Sarah Clifford and Panos Mavrokonstantis Tax Enforcement using a Hybrid between Self-and Third-Party Reporting

WP19/10 Miguel Almunia, Irem Guceri, Ben Lockwood, Kimberley Scharf More giving or more givers? The effects of tax incentives on charitable donations in the UK

WP19/09 Itai Grinberg Stabilizing "pillar one" corporate profit reallocation in an uncertain environment

WP19/08 Joel Slemrod, Obeid Ur Rehman, Mazhar Waseem Pecuniary and non-pecuniary motivations for tax compliance: evidence from Pakistan

WP19/07 Enda Hargaden, Barra Roantree Does statutory incidence matter? Earnings responses to social security contributions

WP19/06 Lucie Gadenne, Tushar K. Nandi, Roland Rathelot Taxation and supplier networks: evidence from India

WP19/05 Thiess Buettner, Boryana Madzharova Unit sales and price effects of preannounced consumption tax reforms: micro-level evidence from European VAT 
WP19/04 Katarzyna Bilicka, Yaxuan Qi, Jing Xing Debt reallocation in multinational firms: evidence from the UK worldwide debt cap

WP19/03 Reuven Avi-Yonah, Orli Avi-Yonah, Nir Fishbien and Haiyan Xu Bridging the redblue divide: a proposal for US Regional Tax Relief

WP19/02 Elizabeth Gugl, George R. Zodrow Tax competition and the efficiency of "benefitrelated" business taxes

WP19/01 Michael P Devereux, Alan Auerbach, Michael Keen, Paul Oosterhuis, Wolfgang Schön and John Vella Residual profit allocation by income

WP18/22 Ronny Freier, Martin Simmler and Christian Wittrock Public good provision, commuting and local employment

WP18/21 Christian Wittrock Localization Economies and the Sensitivity of Firm Foundations to Changes in Taxation and Public Expenditures

WP18/20 Nadine Riedel, Martin Simmler and Christian Wittrock Local fiscal policies and their impact on the number and spatial distribution of new firms

WP18/19 Leonie Hug and Martin Simmler How cost-effective is public R\&D in stimulating firm innovation?

WP18/18 Wiji Arulampalam and Andrea Papini Tax Progressivity and Self-Employment Dynamics

WP18/17 Wiji Arulampalam, Michael P Devereux and Federica Liberini Taxes and the Location of Targets

WP18/16 Frank M Fossen, Ray Rees, Davud Rostam-Afschaf and Viktor Steiner How do Entrepreneurial Portfolios Respond to Income Taxation

WP18/15 Sebastian Beer, Ruud de Mooij and Li Liu International Corporate Tax Avoidance: A Review of the Channels, Magnitudes and Blind Spots

WP18/14 Daisy Ogembo Are Presumptive Taxes a Good Option for Taxing Self-Employed Professionals in Developing Countries

WP18/13 Ilan Benshalom The Rise of Inequality and the fall of Tax Equity

WP18/12 Thomas Torslov, Ludwig Weir and Gabriel Zucman The Missing Profits of Nations

WP18/11 Andrea Lassman and Benedikt Zoller-Rydzek Decomposing the Margins of Transfer Pricing 
WP18/10 Travis Chow, Jeffrey L Hoopes and Edward L Maydew US Firms on Foreign (tax) Holidays

WP18/09 Claudio Agostini, Juan Pablo Atal and Andrea Repetto Firms Response to Tax Enforcement through Audits

WP18/08 Mazhar Waseem Information, Asymmetric Incentives or Withholding? Understanding the Self-Enforcement of Value-Added-Tax

WP18/07 Matthew Smith, Danny Yagan, Owen Zidar and Eric Zwick Capitalists in the twenty-first century

WP18/06 Daniel Shaviro The new non-territorial U.S international tax system

WP18/05 Eric M Zolt Tax Treaties and Developing Countries

WP18/04 Anne Brockmeyer, Marco Hernandez, Stewart Kettle and Spencer Smith Casting a wider tax net: Experimental evidence from Costa Rica

WP18/03 Ruud de Mooij and Li Liu At a cost:the real effects of transfer pricing regulations

WP18/02 Rita de la Feria Tax fraud and the rule of law

WP18/01 Eddy Hiu Fung Tam Behavioural response to time notches in transaction tax: Evidence from stamp duty in Hong Kong and Singapore

WP17/19 Michael P. Devereux, Giorgia Maffini and Jing Xing Corporate tax incentives \& capital structure: New evidence from UK firm-level tax returns

WP17/18 Sarah Clifford Taxing Multinationals beyond borders: financial and locational responses to CFC rules

WP17/17 Dominik von Hagen and Axel Prettl Controlled foreign corporation rules and crossborder M\&A activity

WP17/16 Marie Lamensch Destination based taxation of corporate profits - preliminary findings regarding tax collection in cross-border situations

WP17/15 Li Liu Tim Schmidt-Eisenlohr and Dongxian Guo International transfer pricing and tax avoidance: Evidence from linked trade-tax statistics in the UK.

WP17/14 Katarzyna Habu How much tax do companies pay in the UK?

WP17/13 Katarzyna Habu How aggressive are foreign multinational companies in reducing their corporation tax liability?

WP17/12 Edward D. Kleinbard The right tax at the right time 
WP17/11 Aaron Flaaen The role of transfer prices in profit-shifting by U.S. multinational firms: Evidence from the 2004 Homeland Investment Act

WP17/10 Ruud de Mooij and Li Liu At a cost: The real effect of transfer pricing regulations on multinational investments

WP17/09 Wei Cui Taxation without information: The institutional foundations of modern tax collection

WP17/08 John Brooks The definitions of income

WP17/07 Michael P. Devereux and John Vella Implications of Digitalization for International Corporation Tax Reform

WP17/06 Richard Collier and Michael P. Devereux The Destination-Based Cash Flow Tax and the Double Tax Treaties

WP17/05 Li Liu Where does multinational investment go with Territorial Taxation

WP17/04 Wiji Arulampalam, Michael P Devereux and Federica Liberini Taxes and Location of Targets

WP17/03 Johannes Becker and Joachim Englisch A European Perspective on the US plans for a Destination based cash flow tax

WP17/02 Andreas Haufler, Mohammed Mardan and Dirk Schindler Double tax discrimination to attract FDI and fight profit shifting: The role of CFC rules

WP17/01 Alan Auerbach, Michael P. Devereux, Michael Keen and John Vella Destinationbased cash flow taxation

WP16/14 Anzhela Cédelle The EU Anti-Tax Avoidance Directive: A UK Perspective

WP16/13 Michael Devereux Measuring corporation tax uncertainty across countries: Evidence from a cross-country survey

WP16/12 Andreas Haufler and Ulf Maier Regulatory competition in capital standards with selection effects among banks

WP16/11 Katarzyna Habu Are financing constraints binding for investment? Evidence from natural experiment

WP 16/10 Li Liu and Ben Lockwood VAT notches, voluntary registration and bunching: Theory and UK evidence

WP 16/09 Harry Grubert and Roseanne Altshuler Shifting the burden of taxation from the corporate to the personal level and getting the corporate tax rate down to 15 percent 
WP 16/08 Margaret K McKeehan and George R Zodrow Balancing act: weighing the factors affecting the taxation of capital income in a small open economy

WP 16/07 Michael P Devereux and Li Liu Stimulating investment through incorporation

WP 16/06 Stephen R Bond and Irem Guceri R\&D and productivity: Evidence from large UK establishments with substantial $R \& D$ activities

WP16/05 Tobias Böhm, Nadine Riedel and Martin Simmler Large and influential: firm size and governments' corporate tax rate choice?

WP16/04 Dhammika Dharmapala The economics of corporate and business tax reform

WP 16/03 Rita de la Feria EU VAT principles as interpretative aids to EU VAT rules: the inherent paradox

WP 16/02 Irem Guceri Will the real R\&D employees please stand up? Effects of tax breaks on firm level outcomes

WP 16/01 Giorgia Maffini, Jing Xing and Michael P Devereux The impact of investment incentives: evidence from UK corporation tax returns

WP 15/33 Anzhela Cédelle Enhanced co-operation: a way forward for tax harmonisation in the EU?

WP 15/32 James Mahon and Eric Zwick Do experts help firms optimise?

WP 15/31 Robin Boadway, Motohiro Sato and Jean-François Tremblay Cash-flow business taxation revisited: bankruptcy, risk aversion and asymmetric information

WP 15/30 Martin Simmler Do multinational firms invest more? On the impact of internal debt financing and transfer pricing on capital accumulation

WP 15/29 Daniel Shaviro The crossroads versus the seesaw: getting a 'fix' on recent international tax policy developments

WP 15/28 Zhonglan Dai, Douglas A Shackelford, Yue (Layla) Ying and Harold H Zhang Do companies invest more after shareholder tax cuts?

WP 15/27 Martin Ruf and Julia Schmider Who bears the cost of taxing the rich? An empirical study on CEO pay

WP 15/26 Eric Orhn The corporate investment response to the domestic production activities deduction 
WP 15/25 Li Liu International taxation and MNE investment: evidence from the UK change to territoriality

WP 15/24 Edward D Kleinbard Reimagining capital income taxation

WP 15/23 James R Hines Jr, Niklas Potrafke, Marina Riem and Christoph Schinke Inter vivos transfers of ownership in family firms

WP 15/22 Céline Azémar and Dhammika Dharmapala Tax sparing agreements, territorial tax reforms, and foreign direct investment

WP 15/21 Wei Cui A critical review of proposals for destination-based cash-flow corporate taxation as an international tax reform option

WP 15/20 Andrew Bird and Stephen A Karolyi Governance and taxes: evidence from regression discontinuity

WP 15/19 Reuven Avi-Yonah Reinventing the wheel: what we can learn from the Tax Reform Act of 1986

WP 15/18 Annette Alstadsæter, Salvador Barrios, Gaetan Nicodeme, Agnieszka Maria Skonieczna and Antonio Vezzani Patent boxes design, patents, location and local R\&D

WP 15/17 Laurent Bach Do better entrepreneurs avoid more taxes?

WP 15/16 Nadja Dwenger, Frank M Fossen and Martin Simmler From financial to real economic crisis: evidence from individual firm-bank relationships in Germany

WP 15/15 Giorgia Maffini and John Vella Evidence-based policy-making? The Commission's proposal for an FTT

WP 15/14 Clemens Fuest and Jing Xing How can a country 'graduate' from procyclical fiscal policy? Evidence from China?

WP 15/13 Richard Collier and Giorgia Maffini The UK international tax agenda for business and the impact of the OECD BEPS project

WP 15/12 Irem Guceri and Li Liu Effectiveness of fiscal incentives for R\&D: quasiexperimental evidence

WP 15/11 Irem Guceri Tax incentives and R\&D: an evaluation of the 2002 UK reform using micro data

WP 15/10 Rita de la Feria and Parintira Tanawong Surcharges and penalties in UK tax law

WP 15/09 Ernesto Crivelli, Ruud de Mooij, Michael Keen Base erosion, profit-shifting and developing countries 
WP 15/08 Judith Freedman Managing tax complexity: the institutional framework for tax policy-making and oversight

WP 15/07 Michael P Devereux, Giorgia Maffini and Jing Xing Corporate tax incentives and capital structure: empirical evidence from UK tax returns

WP 15/06 Li Liu and Ben Lockwood VAT notches

WP 15/05 Clemens Fuest and Li Liu Does ownership affect the impact of taxes on firm behaviour? Evidence from China.

WP 15/04 Michael P Devereux, Clemens Fuest and Ben Lockwood The taxation of foreign profits: a unified view

WP 15/03 Jitao Tang and Rosanne Altshuler The spillover effects of outward foreign direct investment on home countries: evidence from the United States

WP 15/02 Juan Carlos Suarez Serrato and Owen Zidar Who benefits from state corporate tax cuts? A local labour markets approach with heterogeneous firms

WP 15/01 Ronald B Davies, Julien Martin, Mathieu Parenti and Farid Toubal Knocking on Tax Haven's Door: multinational firms and transfer pricing 